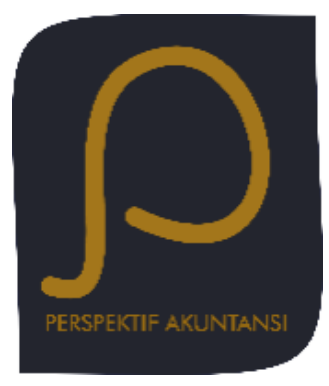

Perspektif Akuntansi Volume 4 Nomor 2 (Juni 2021), hal. 175-216 ISSN: 2623-0194 (Print), 2623-0186 (Online) Copyright(C The Authors(s). All Rights Reserved Center for Accounting Development and Research (CARD)

Fakultas Ekonomika dan Bisnis,

Universitas Kristen Satya Wacana

DOI: https://doi.org/10.24246/persi.vXiX.p175-216 http://ejournal.uksw.edu/persi

\title{
Sales Growth dan Tax Avoidance dengan Kepemilikan Institusional Sebagai Variabel Pemoderasi
}

\author{
Nora Safitri ${ }^{1}$ \\ Universitas Kristen Satya Wacana \\ Theresia Woro Damayanti \\ Universitas Kristen Satya Wacana
}

Received

$14 / 04 / 2021$

Revised

$30 / 06 / 2021$

Accepted $30 / 06 / 2021$

\begin{abstract}
Tax is an instrument that is needed in reducing the gap of state revenue, but, in fact, the tax revenue hasn't reached the target yet due to tax avoidance. Some companies think that doing tax avoidance is a legal practice. The purpose of this study is to determine whether sales growth affects tax avoidance with institutional ownership as a moderating variable. The study was conducted on manufacturing companies listed on the Indonesia Stock Exchange in the period 2010-2017 obtained using the purposive sampling method. Data analysis uses descriptive statistics, stationarity test, and panel data regression analysis. This study shows that sales growth has a positive effect on tax avoidance, which means that when a company's sales growth is high, the company actually uses tax avoidance practices. This study also proves that institutional ownership can moderate the effect of sales growth on tax avoidance.
\end{abstract}

Keywords: Tax avoidance, sales growth,ownership institusional 


\begin{abstract}
Abstrak. Pajak merupakan instrumen yang sangat dibutuhkan untuk mengurangi kesenjangan penerimaan negara, namun pada kenyataannya penerimaan perpajakan belum mencapai target karena adanya penghindaran pajak. Tujuan dari penelitian ini adalah untuk mengetahui apakah pertumbuhan penjualan mempengaruhi penghindaran pajak dengan kepemilikan institusional sebagai variabel moderasi. Penelitian dilakukan pada perusahaan manufaktur yang terdaftar di Bursa Efek Indonesia periode 2010-2017 yang diperoleh dengan menggunakan metode purposive sampling. Analisis data menggunakan statistik deskriptif, uji stasioneritas, dan analisis regresi data panel. Hasil penelitian menunjukkan bahwa pertumbuhan penjualan berpengaruh positif terhadap penghindaran pajak yang berarti bahwa ketika sales growth suatu perusahaan tinggi maka perusahaan tersebut justru memanfaatkan praktik tax avoidance. Studi ini juga membuktikan bahwa kepemilikan institusional dapat memoderasi pengaruh sales growth terhadap tax avoidance.
\end{abstract}

Kata kunci: Penghindaran pajak, pertumbuhan penjualan, kelembagaan kepemilikan

\title{
Pendahuluan
}

Pajak adalah instrumen yang diperlukan dalam mengurangi kesenjangan pendapatan negara. Tetapi pada realisasinya penerimaan pajak tahun 2014 hingga tahun 2017 masih juga belum mencapai target, bahkan di tahun 2017 terakhir ini target yang dicapai hanya 89,4\% dari target APBN 2017 sebesar Rp. 128,3 triliun. Terdapat beberapa penyebab yang dapat mempengaruhi perusahaan melakukan tax avoidance seperti profitabilitas, sales growth, dan kepemilikan institusional (Andalia, 2018). Sebagai contoh, suatu perusahaan melakukan tax avoidance dengan meminimalkan jumlah pajak yang harus dibayarkan perusahaan dengan manajemen pajak yang salah satunya yaitu perencanaan pajak. Melalui hal tersebut, sebagian perusahaan beranggapan bahwa melakukan tax avoidance adalah praktik yang legal, asalkan dengan tidak melanggar undang-undang perpajakan yang berlaku. Padahal disisi lain melakukan tax avoidance akan merugikan negara karena penerimaan negara menjadi berkurang.

Tidak tercapainya target penerimaan Negara dalam sektor pajak dikarenakan adanya tindak penghindaran pajak. Berdasarkan data target dan realisasi penerimaan pajak yang telah dipublikasikan dalam Laporan Kinerja Direktorat Jenderal Pajak (DJP) pada tahun 2015 hingga tahun 2018, dapat dilihat sebagai berikut : 
Tabel 1. Target dan Realisasi Penerimaan Pajak Tahun 2014-2017 (dalam Triliun Rp)

\begin{tabular}{ccccc}
\hline Tahun & 2014 & 2015 & 2016 & 2017 \\
\hline Target Pajak & $1.027,37$ & $1.294,26$ & $1.355,20$ & $1.283,56$ \\
Realisasi Pajak & 981,83 & $1.060,83$ & $1.105,81$ & $1.151,13$ \\
Presentase Penerimaan Pajak & $91,56 \%$ & $81,96 \%$ & $81,60 \%$ & $89,68 \%$ \\
\hline
\end{tabular}

Sumber: Menu Kinerja Penerimaan Portal Direktoral Jenderal Pajak, 2017

Pada Tabel 1 memperlihatkan bahwa realisasi penerimaan Negara yang bersumber dari sektor pajak belum juga mencapai target yang diharapkan, justru penerimaan pajak yang diterima selalu mengalami fluktuasi. Presentase capaian penerimaan pajak dari tahun 2014 ke tahun 2015 mengalami penurunan sebesar 9,6\%, kemudian tahun 2015 ke tahun 2016 mengalami penurunan sebesar 0,36\%. Dan Mulai tahun 2016 ke tahun 2017 mulai mengalami peningkatan, walaupun mengalami peningkatan dalam penerimaan pajak, pada realisasi penerimaan pajak masih belum mencapai target yang diinginkan. Menurut Laporan Kinerja Direktorat Jenderal Pajak (2017), penurunan presentase penerimaan pajak ini disebabkan oleh salah satunya penurunan PPh pasal 25/29 Badan yang terlihat dari penurunan semua jenis setoran seperti setoran Tahunan, STP, dan SKPKB.

Fenomena praktik tax avoidance yang dilakukan perusahaan terlihat dari rendahnya presentase setoran pajak. Selain itu, DJP dapat menerbitkan Surat Ketetapan Pajak Kurang Bayar (SKPKB) apabila perusahaan kurang membayar pajak terutangnya dan tidak mematuhi peraturan yang ditetapkan. SKPKB ialah surat ketetapan pajak yang terdiri atas besar pembayaran pokok pajak, jumlah pokok pajak, jumlah kredit pajak, jumlah sanksi administrasi, serta jumlah yang masih harus dibayarkan. Perusahaanperusahaan di Indonesia yang mendapatkan SKPKB khususnya perusahaan manufaktur pada tahun 2015 terdapat 10 perusahaan dengan nilai SKPKB Rp. 136.639.677.300, pada tahun 2016 terdapat 15 perusahaan dengan nilai SKPKB Rp. 318.842.492.365, dan tahun 2017 sebanyak 12 perusahaan dengan nilai SKPKB Rp. 82.338.507.889 (Indriyanti \& Setiawan, 2019). Salah satu kasus indikasi upaya tax avoidance yang terjadi pada perusahaan manufaktur Wijaya Karya Beton Tbk pada tahun 2015 menerima SKPKB sebesar Rp. 19.123.199.844 untuk jenis penghasilan badan tahun 2015 (Januari \& Suardikha, 2019). Hal ini dapat disimpulkan bahwa perusahaan melakukan tax avoidance agar pajak terutang yang ditanggung lebih sedikit.

Pengaruh strategis yang ada pada penjualan perusahaan harus didorong dengan memiliki harta atau aset. Apabila suatu perusahaan ingin menaikkan tingkat penjualannya maka aset pada perusahaan juga perlu ditambah (Nugroho \& Pengestuti, 2009). Dengan menggunakan pengukuran sales growth, maka perusahaan dapat memprediksi profit yang akan diperoleh dari hasil pertumbuhan penjualan tersebut. Namun, seringkali pada saat mendapatkan profit yang besar, perusahaan justru melakukan praktik tax avoidance (Sholeha, 2019). Menurut Dewinta \& Setiawan (2016) sales growth menggambarkan kemampuan perusahaan dalam meningkatkan penjualannya dari waktu ke waktu. Semakin tinggi tingkat pertumbuhan penjualan suatu perusahaan, maka akan berdampak langsung terhadap 
laba dan pajak perusahaan. Sales growth diduga mempunyai pengaruh positif terhadap tax avoidance. Hal tersebut dibuktikan oleh pendapat beberapa peneliti. Sales growth memiliki pengaruh yang signifikan terhadap adanya tax avoidance (Mahanani, Titisari, \& Nurlaela, 2017), sedangkan penelitian lain berpendapat bahwa sales growth tidak memiliki pengaruh pada tax avoidance (Aprianto \& Dwimulyani, 2019).

Selain sales growth, kepemilikan institusional memungkinkan memiliki pengaruh terhadap tax avoidance, hal ini disebabkan kepemilikan institusional memiliki peran yang penting di dalam perusahaan, seperti mengontrol, mendisiplinkan, serta mempengaruhi manajer (Khurana \& Moser, 2011). Kepemilikan institusional diartikan sebagai persentase saham yang dimiliki oleh institusi pemerintah, institusi keuangan, institusi berbadan hukum dan sebagainya serta kepemilikan investor dengan posisi kepemilikan saham sekurang-kurangnya 5\% (Victory \& Cheisviyani, 2016). Berdasarkan sudut pandang dari hubungan teori keagenan, hal ini akan memicu kecenderungan manajemen untuk mengelola perusahaan demi kepentingannya sendiri dan mengesampingkan kesejahteraan pemilik perusahaan atau pemegang saham. Akan tetapi, dalam praktiknya kepemilikan institusional lebih efektif dalam fungsi pengawasannya dibandingkan dengan kepemilikan manajerial (Arianandini \& Ramantha, 2018). Sehingga, hal ini menunjukkan bahwa kepemilikan institusional berpengaruh terhadap tax avoidance (Cahyono, Andini, \& Raharjo, 2016) dan (Meiza, 2015), disisi lain menurut Pohan (2019), (Winata, 2014), dan (Diantari \& Ulupui, 2016) kepemilikan institusional tidak berpengaruh secara signifikan terhadap tax avoidance. Apabila semakin besar kepemilikan institusional maka semakin kuat kendali yang dilakukan pihak eksternal terhadap perusahaan (Ngadiman \& Puspitasari, 2014), serta dapat mengurangi terjadinya konflik kepentingan manajemen sehingga menekan peluang terjadinya tax avoidance (Diantari \& Ulupui, 2016).

Berdasarkan latar belakang di atas, tax avoidance tersebut terjadi karena adanya kesempatan dalam melakukan perencanaan pajak demi menghindari membayar kewajiban pajak perusahaan. Tax avoidance yang seringkali dilakukan perusahaan sebenarnya tidak bertentangan dengan peraturan undang-undang perpajakan, dengan demikian hal tersebut dianggap praktik yang memanfaatkan celah dalam peraturan undang-undang perpajakan. Namun, hal ini tentu saja akan mempengaruhi penerimaan negara dari sektor pajak. Melalui penelitian ini penting bagi pemerintah untuk mengetahui faktor-faktor yang berpengaruh terhadap tax avoidance dalam perusahaan manufaktur yang terdaftar di BEI, sehingga kedepannya penerimaan pajak negara mencapai target APBN sesuai yang diharapkan. Tujuan dari penelitian ini adalah mengetahui apakah sales growth berpengaruh terhadap tax avoidance dengan kepemilikan institusional sebagai variabel pemoderasi. 


\section{Telaah Pustaka}

\section{Tax avoidance}

Tax avoidance ialah pengaturan untuk meminimalkan atau menghilangkan beban pajak yang ditanggung dengan mempertimbangkan akibat yang dapat diterima kedepannya (Kurniasih \& Sari, 2013). Menurut pendapat lain, tax avoidance adalah sebagai segala sesuatu yang mengurangi besarnya beban pajak yang harus dibayarkan atau ETR (effective tax rate) perusahaan untuk waktu yang lama, misalnya 10 tahun (Dyreng, Hanlon, \& Maydew, 2008). Kelemahan yang ada dalam undang-undang perpajakan menjadi celah untuk melakukan tax avoidance baik secara legal maupun non legal. Skema tax avoidance yang dilakukan ada dua, yang pertama dengan upaya meminimalkan pembayaran pajak dengan tidak melanggar peraturan perpajakan yang ada, yang kedua dengan melakukan tindakan tax avoidance, hal ini sudah termasuk melanggar undang-undang perpajakan (Yulyanah \& Kusumastuti, 2019). Upaya meminimalisasi pajak seringkali disebut dengan perencanaan pajak (tax planning). Secara umum, perencanaan pajak yang dilakukan perusahaan melihat pada proses merekayasa usaha serta transaksi wajib pajak agar utang pajak yang ditanggung berada pada jumlah yang minimum, namun tetap sesuai peraturan perpajakan (N. A. Annisa \& Kurniasih, 2008).

\section{Sales Growth}

Sales growth merupakan hal yang penting di dalam sebuah perusahaan terutama dalam manajemen modal kerja, sehingga perusahaan dapat memprediksi seberapa banyak laba yang telah dihasilkan (Nafis, Manik, \& Fatahurrazak, 2016) dan mengetahui seberapa besar peningkatan jumlah penjualan dari tahun ke tahun (Kennedy \& Suzana, 2011). Menurut Fadjarenie \& Anisah (2014) sales growth merupakan perubahan penjualan pada laporan keuangan yang dapat mencerminkan perspektif dan daya laba perusahaan di tahun mendatang. Kesimpulan dari definisi tersebut, sales growth merupakan perubahan penjualan pada laporan keuangan perusahaan dari tahun ke tahun yang mencerminkan perspektif serta daya laba perusahaan.

\section{Kepemilikan institusional}

Kepemilikan institusional ialah saham yang dimiliki oleh pemerintah, perusahaan asuransi, investor luar negeri maupun bank (Dewi \& Jati, 2014). Semakin besar persentase kepemilikan institusional maka semakin tinggi tingkat pemantauan yang dilakukan oleh pihak eksternal terhadap kinerja manajemen, hal ini akan meningkatkan kinerja manajemen perusahaan untuk mengoptimalkan nilai perusahaannya. Pemegang saham eksternal memiliki hak untuk mengawasi dan mempengaruhi manajemen perusahaan secara wajar dengan tujuan melindungi investasi mereka pada perusahaan tersebut. Rendahnya konflik agensi langsung antara manajemen dan pemegang saham perusahaan disebabkan pengawasan 
pemegang saham eksternal terhadap perilaku manajer yang oportunis (Ngadiman \& Puspitasari, 2014).

\section{Pengaruh antara sales growth terhadap tax avoidance}

Sales growth merupakan indikator penerimaan pasar atas produk atau jasa yang menghasilkan pendapatan bagi perusahaan, serta indikator dari permintaan dan daya saing perusahaan satu dengan perusahaan lain dalam suatu industri (Masrullah, Mursalim, \& Su'un, 2018). Suatu perusahaan dapat memaksimalkan sumber daya yang dimiliki dengan cara melihat seberapa banyak penjualan yang telah dihasilkan oleh perusahaan di tahun sebelumnya (Rahmawati, 2016). Peningkatan penjualan pada perusahaan mencerminkan perusahaan tersebut mendapatkan profit yang juga meningkat. Ketika profit yang diterima oleh perusahaan itu besar, maka beban pajak yang harus dibayarkan oleh perusahaan pun juga besar.

Menurut Hidayat (2018) bahwa perusahaan yang penjualannya relatif stabil memiliki peluang yang lebih aman dalam memperoleh pinjaman serta menanggung beban yang lebih besar dibanding dengan perusahaan yang penjualannya tidak stabil. Selain itu, peluang bisnis yang tersedia di pasar dapat dilihat dari tingkat sales growth perusahaan. Sales growth memiliki peran yang penting di dalam manajemen modal kerja, karena dapat menunjukkan seberapa besar hasil investasi yang diperoleh pada periode masa lalu serta memprediksi seberapa banyak penjualan yang akan didapat dimasa yang akan datang (Rahmawati, 2016). Manajemen sebagai pengambil keputusan dalam perusahaan, tentunya memiliki kesempatan untuk melakukan kebijakan pajak agresif demi memperbaiki laporan keuangan perusahaan (Masrullah, Mursalim, \& Su'un, 2018).

Pajak merupakan beban yang bersifat mengurangi kas perusahaan (Nugraha \& Mulyani, 2019). Semakin baik sales growth pada perusahaan, maka semakin besar pula pengaruh tax planning perusahaan untuk mencapai tax saving yang optimal. Oleh sebab itu, ketika perusahaan mendapatkan profit yang tinggi justru cenderung mengurangi pajak yang harus dibayarkan dengan cara melakukan praktik tax avoidance. Hasil penelitian Nafis et al., (2016) dan Silvia (2017) menunjukkan sales growth memiliki pengaruh positif terhadap adanya tax avoidance, yang artinya apabila suatu perusahaan mengalami peningkatan volume penjualannya maka laba yang dihasilkan akan meningkat, selanjutnya sales growth juga mengalami peningkatan, maka perusahaan mendapat laba yang besar, kemudian perusahaan akan melakukan tax avoidance. Selain itu menurut hasil penelitian Fatimah (2018) berdasarkan teori keagenan, dengan mengurangi biaya pajak dapat berpengaruh terhadap kompensasi yang diterima, karena sales growth memiliki peranan untuk memprediksi seberapa banyak profit yang akan diperoleh sehingga agen bisa melakukan manajemen pajak agar profit yang diterima tetap maksimal, hasil penelitian ini didukung oleh penelitian yang telah dilakukan Nabilla \& ZulFikri (2018) yang berpendapat bahwa sales growth berpengaruh positif terhadap tax avoidance. 
Dari uraian diatas, dapat ditarik hipotesis sebagai berikut :

$\boldsymbol{H}_{1}$ : Sales growth berpengaruh positif terhadap tax avoidance

\section{Pengaruh antara sales growth terhadap tax avoidance dengan kepemilikan institusional}

Terjadinya pertumbuhan penjualan pada perusahaan akan meningkatkan keuntungan yang diterima oleh perusahaan, namun juga sejalan dengan jumlah utang yang harus dibayarkan perusahaan. Fenomena ini diduga menjadi penyebab manajemen untuk melakukan manajemen pajak secara agresif demi keuntungan yang dapat diperoleh. Semakin besar kepemilikan institusional yang dimiliki, maka semakin kecil kemungkinan manajemen perusahaan melakukan tindakan kebijakan pajak agresif. Adanya kepemilikan institusional di dalam perusahaan dapat menimbulkan sikap pengawasan yang ketat terhadap kinerja manajemen, sehingga kinerja perusahaan yang dihasilkan meningkat. Hal ini dapat dijelaskan melalui teori agensi dimana perusahaan yang memiliki principal adalah institusi maka akan melakukan pengawasan yang lebih ketat kepada agennya.

Besar-kecilnya kepemilikan institusional di perusahaan tersebut mempengaruhi pengawasan yang dilakukan. Pemegang saham yang menguasai saham lebih besar dibanding pemegang saham lainnya, dapat mengawasi kebijakan manajemen, sehingga manajemen akan lebih berhati-hati dalam mengambil keputusan, dan menghindari perilaku yang dapat merugikan para pemegang saham. Dapat disimpulkan bahwa semakin besar kepemilikan institusional maka memiliki pengaruh kuat terhadap kendali yang dilakukan oleh pihak eksternal pada perusahaan (Ngadiman \& Puspitasari, 2014). Hal ini dikarenakan pemilik institusional memikirkan dampak jangka panjang akibat dari tindakan pajak agresif (Zemzem \& Ftouhi, 2013). Hasil penelitian tersebut telah sesuai dengan yang dilakukan oleh Diantari \& Ulupui (2016) bahwa semakin tinggi kepemilikan institusional maka semakin besar pengawasan terhadap apa yang dilakukan oleh manajer sehingga dapat mengurangi adanya konflik kepentingan antara manajemen dan mengurangi peluang terjadinya tax avoidance. Dari uraian diatas, dapat ditarik hipotesis sebagai berikut :

$\boldsymbol{H}_{2}$ : Kepemilikan institusional mampu memperlemah pengaruh antara sales growth terhadap tax avoidance.

Berdasarkan penelitian hipotesis diatas, untuk mengetahui pengaruh sales growth terhadap tax avoidance dengan kepemilikan institusional sebagai pemoderasi. Untuk lebih jelas akan tertera dalam skema model penelitian pada gambar 1 di bawah ini : 


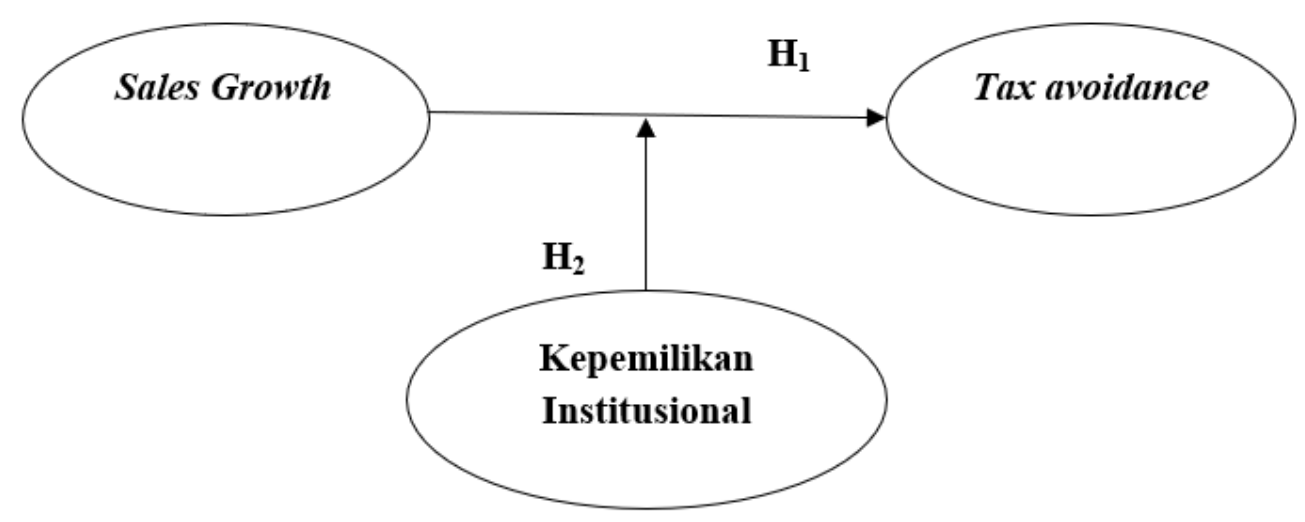

Gambar 1. Model Penelitian

\section{Metoda}

Obyek yang akan diteliti ialah perusahaan manufaktur yang terdaftar di Bursa Efek Indonesia tahun 2014-2017. Penelitian ini menggunakan jenis penelitian kuantitatif, dimana penelitian kuantitatif berfokus pada pengujian teori-teori yang berhubungan dengan variabel penelitian berupa angka dan melakukan analisis data dengan statistika (Renata, 2019). Metode kuantitatif yang digunakan dalam penelitian ini terdiri dari pengujian pengaruh variabel independen yaitu sales growth terhadap variabel dependen yaitu tax avoidance dengan kepemilikan institusional sebagai variabel pemoderasi, dengan profitabilitas dan size sebagai variabel intervening.

Populasi ialah sesuatu yang memiliki karakteristik tertentu yang sudah ditetapkan sebelumnya oleh peneliti untuk dipelajari kemudian ditarik kesimpulannya (Renata et al., 2019). Populasi dalam penelitian ini ialah seluruh perusahaan manufaktur yang terdaftar di BEI periode tahun 2014 sampai dengan 2017. Metode pengambilan sampel yang digunakan adalah purposive sampling, dimana populasi yang akan dijadikan sampel penelitian ini yang memenuhi kriteria sebagai berikut : (1) Perusahaan industri manufaktur yang mempublikasikan laporan keuangan tahunan secara lengkap dan berturut-turut dari tahun 2014-2017 pada situs resmi BEI, (2) Laporan yang disajikan tidak rugi. Namun, penelitian ini juga menambahkan data laporan keuangan tahun 2013 untuk menghitung variabel sales growth.

Variabel independen dalam penelitian ini adalah sales growth yang merupakan perkembangan tingkat penjualan pada perusahaan yang dapat dilihat dari tahun ke tahun (Andriyanto, 2015). Peningkatan sales growth dalam suatu perusahaan sangat berpengaruh terhadap kemampuan perusahaan dalam mempertahankan laba yang akan digunakan untuk mendanai kesempatan yang dimiliki di masa yang akan datang (Ryzki \& Fuadi et al., 2019). Pengukuran ini mengacu pada (Aprianto \& Dwimulyani, 2019) :

Sales Growth=(Penjualan ( $\mathrm{t})-$ Penjualan $(\mathrm{t}-1)) /$ Penjualan 
Variabel dependen dalam penelitian ini adalah tax avoidance yang merupakan kegiatan mengurangi maupun meniadakan hutang pajak yang seharusnya dibayarkan oleh perusahaan dengan tidak melanggar undang-undang yang ada (Wijayani, 2014). Tax avoidance yang biasa dilakukan oleh perusahaan yaitu dengan memanfaatkan celah-celah dalam undang-undang perpajakan. Apabila banyak perusahaan melakukan praktik tax avoidance, maka akan berpengaruh terhadap penerimaan negara dari sektor pajak (Ryzki \& Fuadi, 2019). Pengukuran tax avoidance menggunakan model Cash Effective Tax Rate (CETR) yang bertujuan untuk mengidentifikasi keagresifan perencanaan pajak pada perusahaan yang menjadi objek penelitian. Sehingga dapat dirumuskan sebagai berikut (Hanlon \& Heitzman, 2010) :

Tax Avoidance=(Beban pajak) $/($ Laba sebelum pajak $)$.

Variabel moderasi dalam penelitian ini adalah kepemilikan institusional merupakan kepemilikan saham yang dimiliki oleh lembaga atau institusi lain seperti bank, perusahaan asuransi, perusahaan investasi,dan kepemilikan saham lain yang ada pada perusahaan tersebut (Claudia \& Ekadjaja, 2013). Besar kecilnya kepemilikan institusional pada suatu perusahaan akan berpengaruh terhadap kebijakan pajak agresif perusahaan. Pemilik institusional seharusnya bisa mengontrol manajer agar lebih fokus pada kinerja ekonomi perusahaan dan menghindari peluang untuk mementingkan dirinya sendiri, namun tentu saja hal ini juga berdasarkan besar dan hak suara yang dimiliki oleh pemilik institusional (Merslythalia \& Lasmana, 2016). Mengacu pada Aprianto \& Dwimulyani et al., (2019) maka pengukuran kepemilikan institusional adalah :

Kepemilikan institusional=(Jumlah saham yang dimiliki institusi)/(Jumlah saham yang beredar).

Variabel kontrol dalam penelitian ini menggunakan profitabilitas dan firm size. Profitabilitas merupakan rasio yang dapat menunjukkan laba yang diperoleh (Jasmine, 2017) dari hasil kinerja manajemen dalam mengelola perusahaan (Saputra et al., 2019). Pada dasarnya tujuan utama perusahaan yaitu memperoleh laba sebanyak-banyaknya. Namun, peningkatan laba yang ada pada perusahaan akan berdampak langsung terhadap beban pajak yang harus dibayarkan oleh perusahaan (Sholeha, 2019) sehingga profitabilitas dapat mempengaruhi tindakan tax avoidance yang dilakukan perusahaan (Ariawan \& Setiawan, 2017). Dalam penelitian ini, tingkat profitabilitas diukur menggunakan ROA dikarenakan return on asset (ROA) berkaitan dengan laba bersih perusahaan serta pajak penghasilan yang ditanggung oleh perusahaan (Praditasari \& Setiawan, 2017). Mengacu pada Sholeha et al., 2019 maka pengukuran profitabilitas adalah :

ROA=(Laba bersih setelah pajak)/(Total aset) 
Firm Size merupakan skala pengukuran besar kecilnya suatu perusahaan (Tandean, 2015). Perusahaan yang masuk dalam kategori besar memiliki sumber daya yang melimpah (Dharma \& Ardiana, 2016), serta transaksi yang dilakukan semakin kompleks (Jasmine, 2017). Tahap kedewasaan suatu perusahaan ditandai dengan besarnya total asset yang dimiliki, sehingga menunjukan bahwa perusahaan memiliki prospek baik dalam jangka waktu yang panjang. Hal ini juga menggambarkan perusahaan memiliki laba yang stabil (Dharma \& Ardiana, 2016). Mengacu pada Kurniasih \& Sari (2013) maka pengukuran size adalah :

Size $=\ln ($ total aktiva)

Analisis data penelitian ialah bagian dari proses pengujian data setelah tahap pemilihan dan pengumpulan data dalam suatu penelitian. Analisis data yang digunakan dalam penelitian ini ialah regresi data panel. Pengumpulan data dilakukan dengan mengunduh laporan keuangan dan kemudian ditabulasikan ke dalam microsoft excel. Analisis data panel akan menunjukkan hasil yang lebih jelas ketika data penelitian bersifat time series dan cross section. Teknik analisis data dalam penelitian ini terdiri dari statistik deskriptif, analisis regresi data panel, dan uji model regresi data panel. Analisis data panel akan menunjukkan 3 model yang berbeda untuk kemudian dipilih salah satunya, model tersebut seperti: common effect, fixed effect, dan random effect. Selain itu, ada tiga pengujian yang digunakan sebagai alat pengukuran dalam pemilihan model regresi data panel, yaitu: uji chow, uji hausman, dan uji langrangge multiplier untuk memilih model mana yang terbaik antara common effect dan random effect. Penelitian ini menggunakan program Eviews versi 9 untuk pengolahan data.

Analisis dilakukan dengan menggunakan regresi data panel yaitu analisis regresi yang dalam pengolahan datanya menggunakan data panel. Data panel yaitu data gabungan antara data time series dan cross section (Zulaecha \& Mulvitasari, 2014). Data diambil dengan mengamati dari beberapa individu yang digunakan sebagai sampel dalam kurun waktu tertentu, dengan persamaan regresi sebagai berikut:

$\mathrm{TA}=\alpha+\beta 1 \mathrm{SG}+\beta 2 \mathrm{SG} * \mathrm{KI}+\beta 3 \mathrm{SZ}+\beta 4 \mathrm{PR}+\varepsilon$

Keterangan:

$\mathrm{TA}=$ Tax Avoidance

$\mathrm{SG}=$ Sales Growth

$\mathrm{KI}=$ Kepemilikan Institusional

$\mathrm{SZ}=$ Size Perusahaan

$\mathrm{PR}=$ Profitabilitas

Hipotesis dinyatakan diterima jika nilai probabilitasnya kurang dari $\alpha$ yaitu 1\%, 5\% dan $10 \%$. Dan sebaliknya hipotesis dinyatakan ditolak jika nilai probabilitasnya lebih dari $\alpha$. 


\section{Hasil dan Pembahasan}

\section{Hasil}

Populasi yang digunakan dalam penelitian ini adalah semua perusahaan manufaktur yang terdaftar di Bursa Efek Indonesia tahun 2014-2017. Sampel yang digunakan dalam penelitian ini sebanyak 35 perusahaan manufaktur yang dipilih dengan menggunakan metode purposive sampling berdasarkan atas kriteria pemilihan sampel berikut ini

Tabel 2. Sampel Perusahaan Manufaktur

\begin{tabular}{cc}
\hline Kriteria Sampel & Jumlah Perusahaan \\
\hline $\begin{array}{c}\text { Perusahaan manufaktur yang terdaftar di BEI } \\
\text { Perusahaan manufaktur yang tidak mempublikasikan } \\
\text { laporan keuangan tahunan secara lengkap dan } \\
\text { berturut-turut tahun 2014-2017 }\end{array}$ & 154 \\
Perusahaan manufaktur yang menyajikan laporan & $(12)$ \\
keuangan rugi selama tahun 2014-2017 & \\
Outlier Data & $165)$ \\
Jumlah Sampel & $(42)$ \\
Tahun Observasi & 35 \\
Jumlah Observasi 2014-2017 & 4 \\
\hline
\end{tabular}

\section{Statistik Deskriptif}

Jenis data penelitian adalah data panel, yakni gabungan dari data time series dan data cross section. Penelitian menguji 35 perusahaan yang terdaftar di BEI sebagai data cross section, selama empat tahun mulai tahun 2014 sampai dengan 2017 sebagai data time series. Data dalam penelitian ini terdiri dari sales growth sebagai variabel bebas, tax avoidance (ETR) sebagai variabel terikat, kepemilikan institusional sebagai variabel pemoderasi, profitabilitas (ROA) dan firm size sebagai variabel kontrol. Tabel analisis deskriptif berikut ini bertujuan untuk menyajikan gambaran dari variabelvariabel penelitian yang diolah menggunakan aplikasi EViews versi 8.

\section{Tabel 3. Statistik Deskriptif}

\begin{tabular}{cccccc}
\hline Variable & Observations & Mean & Maximum & Minimum & $\begin{array}{c}\text { Std. } \\
\text { Deviation }\end{array}$ \\
\hline Tax Avoidance & 140 & 0,9491 & 63,2500 & $-0,2531$ & 5,3509 \\
Sales Growth & 140 & 1,4073 & 51,6287 & $-24,3219$ & 6,3593 \\
Kepemilikan & 140 & 0,1451 & 0,3024 & 0,10394 & 0,0374 \\
Institusional & & & & & \\
$\quad$ Firm size & 140 & 0,0004 & 0,0066 & 0,0031 & 0,0006 \\
Profitabilitas & 140 & 2,7942 & 20,5889 & 0,4812 & 2,7423 \\
\hline
\end{tabular}

Effective Tax Rate (ETR) digunakan dalam penelitian untuk mengukur variabel tax avoidance sebagai variabel terikat. Berdasarkan hasil analisis deskriptif diatas, dapat dilihat bahwa nilai maksimum dari variabel tax avoidance adalah 63,2500 dan nilai minimum adalah $-0,2531$. Nilai rata-rata (mean) sebesar 0,9491 dengan standar deviasi 5,3509. Sales growth memiliki nilai maksimum sebesar 51,6287 dan nilai minimum sebesar $-24,3219$. Nilai rata-rata (mean) sebesar 1,4073 dengan standar deviasi 6,3593. 
Berdasarkan hasil analisis deskriptif di atas, dapat dilihat bahwa nilai maksimum dari variabel kepemilikan institusional 0,3024 dan nilai minimum adalah 0,10394 . Nilai rata-rata (mean) sebesar 0,1451 dengan standar deviasi 0,0374. Sedangkan, dari tabel analisis deskriptif menyatakan bahwa nilai maksimum dari firm size adalah 0,0066 dan nilai minimum sebesar 0,0031. Nilai rata-rata (mean) sebesar 0,0004 dengan standar deviasi 0,0006. Menurut hasil analisis deskriptif pada variabel return on asset, didapat 20,5889 sebagai nilai maksimum dan 0,4812 sebagai nilai minimum. Nilai rata-rata (mean) dari return on asset sebesar 2,7942 dengan standar deviasi 2,7423 .

\section{Uji Stasioneritas}

Pada penelitian ini uji stasioneritas dilakukan menggunakan uji unit root. Pengujian tingkat stasioneritas data menggunakan levin, lin \& chu (LLC) untuk pengujian stasioneritas secara keseluruhan dan augmented dickey fuller (ADF) untuk pengujian stasioneritas masing-masing observasi. Data dianggap stasioner apabila nilai probabilitasnya kurang dari 0,05, dan dianggap tidak stasioner ketika nilai probabilitasnya diatas 0,05 . Berikut merupakan hasil uji unit root dari masing-masing data penelitian.

Tabel 4. Hasil Uji Unit Root

\begin{tabular}{cccccc}
\hline Variable & \multicolumn{2}{c}{ Levin, Lin \& Chu t* } & \multicolumn{2}{c}{ ADF - Fisher Chi-square } & Note \\
& Statistic & Prob. & Statistic & Prob. & \\
\hline ETR & $-18,4247$ & 0,0000 & 107,025 & 0,0029 & Stationer \\
SALES_GROWTH & $-132,255$ & 0,0000 & 106,884 & 0,0030 & Stationer \\
KPMLK_IN & $-8,67321$ & 0,0000 & 78.3362 & 0,0000 & Stationer \\
FIRM_SIZE & $-1,85739$ & 0,0316 & 170,568 & 0,0000 & Stationer \\
ROA & $-68,9898$ & 0,0000 & 120,980 & 0,0002 & Stationer \\
\hline
\end{tabular}

Melalui tabel hasil uji unit root untuk variabel ETR, nilai probabilitas uji levin, lin \& chu menunjukkan angka sebesar 0,0000 <0,05, kemudian probabilitas dari uji augmented dickey fuller 0,0029<0,05. Berdasarkan nilai tersebut dapat disimpulkan bahwa data dari variabel ETR merupakan stasioner pada tingkat level. Kemudian untuk tabel hasil uji unit root untuk variabel sales growth, nilai probabilitas uji levin, lin \& chu menunjukkan angka sebesar $0,0000<0,05$, kemudian probabilitas dari uji augmented dickey fuller $0,0030<0,05$. Berdasarkan nilai tersebut dapat disimpulkan bahwa data dari variabel sales growth merupakan stasioner pada tingkat level.

Pada tabel hasil uji unit root untuk variabel kepemilikan institusional, nilai probabilitas uji levin, lin \& chu menunjukkan angka sebesar 0,0000<0,05, kemudian probabilitas dari uji augmented dickey fuller 0,0000 <0,05. Berdasarkan nilai tersebut dapat disimpulkan bahwa data dari variabel kepemilikan institusional merupakan stasioner pada tingkat level. Sedangkan untuk variabel firm size melalui tabel hasil uji unit root, nilai probabilitas uji levin, lin \& chu menunjukkan angka sebesar 0,0316< 0,05, kemudian probabilitas dari uji augmented dickey fuller 0,0000< 0,05. Berdasarkan nilai tersebut dapat disimpulkan bahwa data dari variabel MC merupakan stasioner pada tingkat level. Selanjutnya, pada variabel ROA, nilai probabilitas uji levin, lin \& chu menunjukkan angka sebesar 0,0000 $<0,05$, kemudian 
probabilitas dari uji augmented dickey fuller 0,0002 <0,05. Berdasarkan nilai tersebut dapat disimpulkan bahwa data dari variabel ROA merupakan stasioner pada tingkat level.

\section{Analisis Regresi Data Panel}

Pengukuran yang digunakan untuk menentukan model regresi data panel yang paling tepat melalui uji statistik $\mathrm{f}$ (uji chow) adalah dengan melihat nilai probabilitas dari cross-section $\mathrm{f}$, kemudian bandingkan dengan derajat signifikansi sebesar 0,05. Apabila nilai probabilitas cross-section $\mathrm{f}$ kurang dari 0,05 maka dapat disimpulkan bahwa model fixed effect adalah model yang paling tepat daripada model common effect. Sedangkan ketika nilai probabilitas cross-section $f$ lebih dari 0,05 maka kesimpulannya model common effect merupakan model yang lebih tepat dibandingkan model fixed effect.

\section{Tabel 5. Hasil Uji Model Regresi}

\begin{tabular}{|c|c|c|c|}
\hline \multicolumn{4}{|c|}{ Panel A: Uji Statistik F (Uji Chow) } \\
\hline Effects Test & Statistic & Prob. & Result \\
\hline Cross-section F & 3,621378 & 0,0000 & \multirow{2}{*}{ Fixed Effect } \\
\hline Cross-section Chi-square & 111,592837 & 0,0000 & \\
\hline \multicolumn{4}{|l|}{ Panel B: Uji Hausman } \\
\hline Test Summary & Chi-Sq. Statistic & Prob. & Result \\
\hline Cross-section random & 2,255254 & 0,8128 & Random Effect \\
\hline \multicolumn{4}{|c|}{ Panel C. Uji lagrange multiplier (LM) } \\
\hline Null (no rand. effect) & Cross-section & Period & Both \\
\hline Alternative & One-sided & One-sided & Botn \\
\hline \multirow[t]{2}{*}{ Breusch-Pagan } & 47,89010 & 1,124687 & 49,01479 \\
\hline & 0.0000 & 0,2889 & 0.0000 \\
\hline
\end{tabular}

Melalui Tabel 5 karena nilai probabilitas dari cross-section $f$ sebesar 0,0000 yang nilainya kurang dari derajat signifikansi sebesar 0,05 , maka dapat disimpulkan untuk penelitian ini model fixed effect lebih tepat untuk digunakan dibandingkan dengan model common effect.

Pada uji hausman yang digunakan sebagai penentu model regresi data panel yang akan digunakan dalam penelitian adalah dengan melihat nilai probabilitas dari crossrandom, kemudian bandingkan dengan derajat signifikansi sebesar 0,05. Apabila nilai probabilitas cross-random kurang dari 0,05 maka dapat disimpulkan bahwa model fixed effect adalah model yang paling tepat daripada model common effect. Sedangkan ketika nilai probabilitas cross-random lebih dari 0,05 maka kesimpulannya model random effect merupakan model yang lebih tepat dibandingkan model fixed effect. Melalui tabel diatas karena nilai probabilitas dari cross-random sebesar 0,8128 yang nilainya lebih dari derajat signifikansi sebesar 0,05, maka dapat disimpulkan untuk penelitian ini model random effect lebih tepat untuk digunakan dibandingkan dengan model fixed effect.

Melalui kedua pengujian pemilihan model regresi data panel sebelumnya, semuanya memberikan hasil yang berbeda, sehingga berdasarkan hasil pengujian tersebut diperlukannya pengujian lagrange multiplier (LM) untuk menentukkan apakah tetap 
memilih random effect ataukah common effect. Pada hasil uji lagrange multiplier (LM) menggunakan metode Breusch Pagan menunjukkan jika nilai P value yaitu sebesar 0,0000 dimana nilai tersebut kurang dari 0,05 . Sehingga dapat disimpulkan metode estimasi terbaik ialah random effect. Berikut ini merupakan hasil analisis regresi dengan metode random effect yang diolah menggunakan EViews versi 8.

\section{Pengujian Hipotesis}

Pengujian dilakukan dengan membandingkan tingkat probabilitas dengan derajat signifikansi sebesar 0,05. Variabel bebas, pemoderasi dan kontrol berpengaruh signifikan terhadap variabel terikat apabila tingkat probabilitas kurang dari 0,05. Berikut hasil uji sebelum dan sesudah moderasi untuk melihat efek setelah dilakukan moderasi kepemilikan institusional.

\section{Tabel 6. Hasil Uji T}

\begin{tabular}{cccc}
\hline Panel A: Sebelum Moderasi & & & \\
\hline Variabel & Coefficient & Prob. (t) & Note \\
Sales Growth & $-0,203998$ & 0,0049 & H1 Diterima \\
Kepemilikan Institusional & 9,121795 & 0,4722 & \\
Return On Asset & 0,212213 & 0,2168 & Variabel Kontrol \\
Firm Size & $-738,4026$ & 0,2980 & Variabel Kontrol \\
C & 26,70915 & 0,5036 & \\
R-squared & 0,074417 & & \\
Adjusted R-squared & 0,046992 & & \\
\hline Panel B: Sesudah Moderasi & & & \\
\hline Variabel & Coefficient & Prob. (t) & \\
Sales Growth & 0,564135 & 0,0214 & Hote Diterima \\
Sales Growth*Kepemilikan & & & \\
Institusional & $-0,538589$ & 0,0012 & Variabel Kontrol \\
Return On Asset & 0,212392 & 0,1892 & Variabel Kontrol \\
Firm Size & $-973,5069$ & 0,1406 & \\
R-squared & 23,32098 & 0,5284 & \\
Adjusted R-squared & 0,115181 & & \\
\hline
\end{tabular}

Pada hasil uji sesudah moderasi kepemilikan institusional dapat dilihat probabilitas dari variabel sales growth $0,0214<\alpha 0,05$ dengan nilai coefficient regresi $(0,564135)$ memiliki arti bahwa sales growth dibawah alpha $(\alpha=0,05)$, sehingga hipotesis penelitian diterima. Semakin tinggi sales growth perusahaan akan meningkatkan laba perusahaan sehingga akan sejalan dengan tingkat beban pajak yang akan ditanggungnya. Hal ini dapat menjadikan manajemen perusahaan cenderung untuk melakukan tax avoidance supaya dapat meminimalkan pajak yang harus dibayarkan kepada pemerintah. Berdasarkan hasil penelitian menunjukkan bahwa sales growth berpengaruh positif terhadap tax avoidance. Hasil pengujian kepemilikan institusional sebagai variabel pemoderasi menunjukkan probabilitas variabel pemoderasi $0,0012<\alpha$ 0,05 dengan nilai coefficient regresi $-0,538589$ memiliki arti bahwa kepemilikan institusional sebagai variabel pemoderasi di bawah alpha $(\alpha=$ 0,05). Hal ini berarti bahwa hipotesis dua diterima. Adanya kepemilikan institusional di dalam perusahaan dapat menimbulkan sikap pengawasan yang ketat terhadap kinerja manajemen, sehingga kinerja perusahaan yang dihasilkan meningkat. Hal ini 
dapat dijelaskan melalui teori agensi dimana perusahaan yang memiliki principal adalah institusi maka akan melakukan pengawasan yang lebih ketat kepada agennya.

Berdasarkan hasil penelitian menunjukkan bahwa kepemilikan institusional mampu memoderasi pengaruh sales growth terhadap variabel tax avoidance. Kemudian probabilitas dari variabel firm size 0,1406 > 0,05 dengan nilai coefficient regresi 973,569 memiliki arti bahwa firm size tidak berpengaruh secara negatif dan tidak signifikan terhadap ETR atau tax avoidance.Sedangkan probabilitas dari variabel ROA $0,1892>\alpha 0,05$ dengan nilai coefficient regresi $(0,212392)$ memiliki arti bahwa return on assets tidak berpengaruh secara positif dan tidak signifikan terhadap ETR atau tax avoidance.

Uji koefisien determinasi merupakan pengujian yang dilakukan untuk mengetahui baik atau tidaknya model regresi yang terestimasi. Pengujian ini menggunakan nilai adjusted $r$-squared dalam menilai tingkat baik atau tidaknya model regresi yang digunakan. Nilai koefisien determinasi berada diantara angka 0 dan 1, apabila hasil pengujian mendekati angka 0 maka kemampuan variabel-variabel bebas dalam menjelaskan variabel terikat dinilai rendah atau terbatas. Tetapi jika hasil pengujian mendekati angka 1 maka variabel-variabel bebas penelitian dianggap dapat menjelaskan variabel bebas secara keseluruhan. Berdasarkan hasil uji koefisien determinasi, didapat nilai adjusted r-squared sebesar 0,147009. Nilai tersebut memiliki arti bahwa sales growth, kepemilikan institusional, firm size, dan ROA dapat menjelaskan ETR sebesar 14,7\%, sedangkan sisanya dipengaruhi oleh variabel lain diluar penelitian ini. Dapat disimpulkan bahwa model regresi belum cukup baik karena determinasi mendekati angka 0 dinilai rendah atau terbatas, sehingga tidak mampu menjelaskan data aktualnya.

\section{Pembahasan}

Hasil penelitian untuk variabel independen yakni sales growth menunjukkan bahwa sales growth memiliki pengaruh yang positif dan signifikan terhadap tax avoidance (ETR). Hasil pengujian menunjukkan tingkat signifikansi 0,0214 dengan $(\alpha)=0,05$. Sehingga dapat disimpulkan bahwa hasil penelitian mendukung hipotesis yang menyatakan bahwa sales growth berpengaruh positif terhadap tax avoidance. Hal ini sesuai dengan hasil penelitian Mahanani et al., (2017), Nafis et al., (2016)dan Silvia (2017) sales growth berpengaruh terhadap tax avoidance. Hasil ini menunjukkan semakin tinggi rasio sales growth maka semakin tinggi pula laba yang didapat oleh suatu perusahaan, pada dasarnya tujuan suatu perusahaan ialah mendapatkan laba semaksimal mungkin demi terpenuhinya kebutuhan pihak manajemen serta share holder (Panjaitan \& Mulyani, 2020). Maka kesimpulannya yaitu perusahaan justru memanfaatkan sales growth untuk melakukan praktik tax avoidance, komponen yang digunakan berupa retur penjualan untuk menekan tingkat penjualan bersih pada perusahaan, sehingga kecilnya penjualan bersih yang diperoleh berpengaruh terhadap pembayaran pajak yang ditanggung perusahaan. 
Hasil penelitian untuk variabel pemoderasi ialah kepemilikan institusional menunjukkan tingkat signifikasi sebesar 0,0012 dengan $(\alpha)=0,05$ dapat disimpulkan bahwa kepemilikan institusional mampu memoderasi pengaruh antara sales growth terhadap tax avoidance. Penelitian ini sesuai dengan hasil penelitian (Cahyono et al., 2016). Semakin besar kepemilikan institusional yang dimiliki pada perusahaan maka semakin kecil kemungkinan manajemen untuk melakukan kebijakan pajak agresif dikarenakan semakin kuatnya kendali yang dimiliki kepemilikan institusional yang terdiri dari bank, perusahaan asuransi, perusahaan investasi maupun kepemilikan institusi lainnya untuk mengawasi manajemen perusahaan(Ngadiman \& Puspitasari, 2014).

Variabel kontrol dalam penelitian terdiri dari profitabilitas dan firm size. Profitabilitas yang diukur menggunakan ROA dalam hasil penelitian menunjukkan bahwa ROA tidak berpengaruh terhadap tax avoidance. Hal ini dikarenakan manajemen tidak akan mengambil risiko guna meminimalkan risiko investasinya dengan melakukan praktik tax avoidanceyang pada dasarnya merupakan aktivitas berisiko.Tax avoidance juga dapat membebankan biaya yang signifikan seperti biaya yang dibayarkan pada konsultan pajak, denda reputasi, denda yang dibayarkan pada otoritas pajak (A. Permata, S. Nurlaela, E. Masitoh , 2018). Sedangkan variabel firm size pada penelitian ini menunjukkan bahwa firm size tidak berpengaruh terhadap tax avoidance. Perusahaan kecil maupun besar tidak berpengaruh terhadap tax avoidance, dikarenakan perusahaan patuh untuk tidak melakukan aktivitas yang melanggar dari ketentuan pajak yang berlaku. Tentunya, perusahaan tidak ingin mengambil risiko dalam proses pemeriksaan atau dikenakan sanksi yang dapat menimbulkan buruknya citra perusahaan. Perhatian dalam pengawasan yang dilakukan oleh fiskus tidak hanya pada perusahaan besar, pada perusahaan kecil juga tidak lepas dari perhatian fiskus, hal ini dilakukan agar perusahaan mengikuti ketentuan perpajakan yang berlaku dan dikenakan pajak sesuai dengan peraturan yang berlaku (Annisa, 2017).

\section{Simpulan}

Berdasarkan hasil analisis yang telah dipaparkan maka dapat disimpulkan bahwa sales growth berpengaruh secara positif terhadap tax avoidance. Ketika sales growth suatu perusahaan tinggi maka perusahaan tersebut justru memanfaatkan praktik tax avoidance dalam meminimalkan pembayaran pajaknya. Selanjutnya hasil analisis yang telah dilakukan menunjukkan kepemilikan institusional dapat memoderasi pengaruh sales growth terhadap tax avoidance. Hal tersebut disebabkan karena semakin besar kepemilikan institusional yang dimiliki pada perusahaan maka semakin kecil kemungkinan manajemen untuk melakukan kebijakan pajak agresif demi mementingkan kepentingan diri sendiri dikarenakan semakin kuatnya kendali yang dimiliki oleh kepemilikan institusional pada perusahaan.

Secara praktis, hasil penelitian ini dapat berimplikasi pada berbagai pihak. Bagi pemerintah, perlu meningkatkan pengawasan pada perusahaan-perusahaan yang khususnya ada di industri dengan kondisi persaingan pasar yang tinggi, karena ada 
kecenderungan penghindaran pajak yang lebih agresif. Selain itu perlu pula untuk mempertimbangkan sisi kepemilikan dalam hal ini kepemilikan institusional dalam pengawasan pajak. Keterbatasan penelitian adalah hasil dari penelitian ini memiliki nilai koefisien determinasi (Adjusted R2) yang cukup rendah, ini berarti selain sales growth dan kepemilikan institusional masih ada faktor lain yang dapat mempengaruhi tax avoidance. Sehingga untuk penelitian selanjutnya diharapkan dapat menambahkan variabel lain yang mempengaruhi terhadap tax avoidance yang tidak diteliti dalam penelitian ini.

\section{Daftar Pustaka}

Andalia. (2018). Pengaruh Kompensasi Eksekutif, Sales Growth, Financial Distress, dan Kompensasi Rugi Fiskal terhadap Tax Avoidance dengan Komisaris Independen sebagai Pemoderasi. In Universitas Negeri Alauddin Makassar.

Andriyanto, H. N. (2015). Pengaruh Return On Assets, Leverage, Corporate Governance, Dan Sales Growth Terhadap Tax Efficience Pada Perusahaan Manufaktur Yang Terdaftar Di Bei Tahun 2009-2012.

Annisa, A., Taufik, T., \& Hanif, R. (2017). Pengaruh Return on Asset, Leverage, Ukuran Perusahaan Dan Koneksi Politik Terhadap Penghindaran Pajak (Studi Empiris Pada Perusahaan Manufaktur Yang Terdaftar Di Bei Periode Tahun 2012-2015). Jurnal Online Mahasiswa Fakultas Ekonomi Universitas Riau, 4(1), 685-698.

Annisa, N. A., \& Kurniasih, L. (2008). Pengaruh Corporate Governance Terhadap Tax Avoidance. 123-136.

Aprianto, M., \& Dwimulyani, S. (2019a). Pengaruh Sales Growth Dan Leverage Terhadap Tax Avoidance Dengan Kepemilikan Institusional Sebagai Variabel Moderasi. 1-10.

Aprianto, M., \& Dwimulyani, S. (2019b). Pengaruh Sales Growth Dan Leverage Terhadap Tax Avoidance Dengan Kepemilikan Institusional Sebagai Variabel Pemoderasi. Prosiding Seminar Nasional Pakar Ke 2, 1-10.

Arianandini, P. W., \& Ramantha, I. W. (2018). Pengaruh Profitabilitas, Leverage, dan Kepemilikan Institusional pada Tax Avoidance. E-Jurnal Akuntansi Universitas Udayana, 22(3), 2088-2116. https://doi.org/10.1017/CB09781107415324.004

Ariawan, I. M. A. R., \& Setiawan, P. E. (2017). Pengaruh Dewan Komisaris Independen, Kepemilikan Institusional, Profitabilitas Dan Leverge Terhadap Tax Avoidance. EJurnal Akuntansi Universitas Udayana, 18(3), 1831-1859.

Cahyono, D. D., Andini, R., \& Raharjo, K. (2016). Pengaruh Komite Audit, Kepemilikan Institusional, Dewan Komisaris, Ukuran Perusahaan (Size), Leverage (Der) Dan Profitabilitas (Roa) Terhadap Tindakan Penghindaran Pajak (Tax Avoidance) Pada Perusahaan Perbankan Yang Listing Bei Periode Tahun 2011 - 2013. Journal Of Accounting, 2(2).

Claudia, W., \& Ekadjaja, A. (2013). Pengaruh Kepemilikan Manajerial, Kepemilikan Institusional, Keputusan Investasi, Keputusan Pendanaan, Dan Profitabilitas Terhadap Nilai Perusahaan. Jurnal Akuntansi, 13(2), 929-944. 
Dewi, N. N. K., \& Jati, I. K. (2014). Pengaruh Karakter Eksekutif, Karakteristik Perusahaan, Dan Dimensi Tata Kelola Perusahaan Yang Baik Pada Tax Avoidance Di Bursa Efek Indonesia.

Dewinta, I. A. R., \& Setiawan, P. E. (2016). Pengaruh Ukuran Perusahaan, Umur Perusahaan, Profitabilitas, Leverage, Dan Pertumbuhan Penjualan Terhadap Tax Avoidance. 14, 1584-1613.

Dharma, I. M. S., \& Ardiana, P. A. (2016). Pengaruh Leverage, Intensitas Aset Tetap, Ukuran Perusahaan, Dan Koneksi Politik Terhadap Tax Avoidance. 15(1), 584-613.

Diantari, P., \& Ulupui, I. (2016). Pengaruh Komite Audit, Proporsi Komisaris Independen, Dan Proporsi Kepemilikan Institusional Terhadap Tax Avoidance. E-Jurnal Akuntansi, 16(1), 702-732.

Dyreng, S. D., Hanlon, M., \& Maydew, E. L. (2008). Long-run corporate tax avoidance. Accounting Review, 83(1), 61-82. https://doi.org/10.2308/accr.2008.83.1.61

Fadjarenie, A., \& Anisah, Y. A. N. (2014). Pengaruh Corporate Governance Terhadap Tax Avoidance Pada Perusahaan Yang Terdaftar Di Bursa Efek Indonesia Tahun 2013. Tax \& Accounting Review, 4 (1)(1), 1-11.

Fatimah, N. (2018). Pengaruh Kepemilikan Institusional , Komite Audit, Ukuran Perusahaan, Profitabilitas, Leverage, dan Pertumbuhan Penjualan terhadap Tax Avoidance SKRIPSI Oleh: Nama: Nurul Fatimah FAKULTAS EKONOMI UNIVERSITAS ISLAM INDONESIA YOGYAKARTA. https://dspace.uii.ac.id/bitstream/handle/123456789/7648/Pengaruh Kepemilikan Institusional, Komite Audit, Ukuran Perusahaan, Profitabilitas, Leverage, Pertumbuhan Penjualan terhadap Tax Avoidance.pdf?sequence=1

Hanlon, M., \& Heitzman, S. (2010). A review of tax research. Journal of Accounting and Economics, 50(2-3), 127-178. https://doi.org/10.1016/j.jacceco.2010.09.002

Hidayat, W. W. (2018). Pengaruh Profitabilitas, Leverage Dan Pertumbuhan Penjualan Terhadap Penghindaran Pajak. Jurnal Riset Manajemen Dan Bisnis (JRMB) Fakultas Ekonomi UNIAT, 3(1), 19-26. https://doi.org/10.36226/jrmb.v3i1.82

Indriyanti, K. D., \& Setiawan, P. E. (2019). Pengaruh Kompensasi Manajemen, Inventory Intensity Ratio, dan Profitabilitas Pada Tax Avoidance. E-Jurnal Akuntansi, 27(2), 1546. https://doi.org/10.24843/eja.2019.v27.i02.p27

Inggit, I. (2019). Kinerja Pajak 2018, Lagi-Lagi Tak Capai Target. CNBC Indonesia. www.cnbcindonesia.com/market/20190103101148-17-48886/kinerja-pajak-2018lagi-lagi-tak-capai-target

Januari, D. M. D., \& Suardikha, I. M. S. (2019). Pengaruh Corporate Social Responsibility, Sales Growth, dan Profitabilitas Terhadap Tax Avoidance. E-Jurnal Akuntansi, 27(3), 16531677. https://doi.org/10.24843/eja.2019.v27.i03.p01

Jasmine, U. (2017). Pengaruh Leverage, Kepemilikan Institusonal, Ukuran Perusahaan, Dan Profitabilitas Terhadap Penghindaran Pajak. 4(1), 1768-1800. https://doi.org/10.1017/CB09781107415324.004

Kennedy, N. A., \& Suzana, A. R. (2011). Faktor - faktor yang mempengaruhi struktur modal pada perusahaan. Jurnal Ekonomi, 19(2), 1-10. 
Khurana, I. K., \& Moser, W. J. (2011). Institutional Ownership and Tax Aggressiveness. SSRN Electronic Journal, 573, 0-42. https://doi.org/10.2139/ssrn.1464106

Kurniasih, T., \& Sari, M. M. R. (2013). Pengaruh Return On Assets, Leverage, Corporate Governance, Ukuran Perusahaan Dan Kompensasi Rugi Fiskal Pada Tax Avoidance. 18(1), 58-66.

Mahanani, A., Titisari, K. H., \& Nurlaela, S. (2017). Pengaruh Karateristik Perusahaan, Sales Growth, dan CSR Terhadap Tax Avoidance. Seminar Nasional IENACO, 732-742.

Masrullah, Mursalim, \& Su'un, M. (2018). Pengaruh Kepemilikan Institusional, Komisaris Independen, Leverage Dan Sales Growth Terhadap Tax Avoidance Pada Perusahaan Manufaktur Di Bursa Efek Indonesia. 16(2), 142-165.

Meiza, R. (2015). Pengaruh Karakteristik Good Corporate Governance Dan Deferred Tax Expense Terhadap Tax Avoidance. Jurnal Akuntansi, 3(1), 1-26.

Merslythalia, D. R., \& Lasmana, M. S. (2016). Pengaruh Kompetensi Eksekutif, Ukuran Perusahaan, Komisaris Independen, Dan Kepemilikan Institusional Terhadap Tax Avoidance. Jurnal Ilmiah Akuntansi Dan Bisnis, 11(2), 117-124.

Nabilla, S. S., \& ZulFikri, I. (2018). Pengaruh Risiko Perusahaan, Leverage (Debtto Equityratio) Dan Pertumbuhan Penjualan Terhadap Penghindaran Pajak (Tax Avoidance) (Studi Empiris pada Perusahaan Manufaktur subsektor makanan \& minuman yang Terdaftar di BEI Tahun 2014-2017).

Nafis, M., Manik, T., \& Fatahurrazak. (2016). Pengaruh Return On Asset (Roa), Capital Intensity, Sales Growth, Debt To Asset Ratio (Dar), Dan Firm Size Terhadap Penghindaran Pajak (Tax Avoidance) Pada Perusahaan Manufaktur Yang Terdaftar Di Bursa Efek Indonesia Periode 2012-2016. Jurusan Akuntansi, Fakultas Ekonomi, 28(2). https://doi.org/10.4234/jjoffamilysociology.28.250

Ngadiman, \& Puspitasari, C. (2014). Pengaruh Leverage, Kepemilikan Institusional, Dan Ukuran Perusahaan Terhadap Penghindaran Pajak (Tax Avoidance) Pada Perusahaan Sektor Manufaktur Yang Terdaftar Di Bursa Efek Indonesia 2010-2012. XVIII(03), 408-421.

Nugraha, M. I., \& Mulyani, S. D. (2019). Peran Leverage Sebagai Pemediasi Pengaruh Karakter Eksekutif, Kompensasi Eksekutif, Capital Intensity, Dan Sales Growth Terhadap Tax Avoidance. 6(2), 301-324.

Nugroho, E., \& Pengestuti, I. R. D. (2009). Analisis Pengaruh Likuiditas, Pertumbuhan Penjualan, Perputaran Modal Kerja, Ukuran Perusahaan Dan Leverage Terhadap Profitabilitas Perusahaan. 1-30.

Pajak, K. K. R. I. D. J. (2017). Laporan Kinerja Direktorat Jenderal Pajak.

Panjaitan, E. S. E., \& Mulyani, S. D. (2020). Dampak Keberadaan Dewan Direksi Wanita Dan Sales Growth Terhadap Tax Avoidance Dengan Moderasi Capital Intensity. Prosiding Seminar Nasional Pakar Ke 3 Tahun 2020, 1-9.

Permata, A. D., Nurlaela, S., \& Masitoh, E. (2018). Pengaruh Size, Age, Profitability, Leverage Dan Sales Growth terhadap Tax Avoidance Pada Perusahaan Sektor Industri Dasar dan Kimia Di BEI. Seminar Nasional Dan The 5th Call for Syariah Paper. 
Pohan, H. T. (2019). Analisis Pengaruh Kepemilikan Institusi, Rasio Tobin Q Akrual Pilihan, Tarif Efektif Pajak, Dan Biaya Pajak Ditunda Terhadap Penghindaran Pajak Pada Perusahaan Publik. Jurnal Informasi, Perpajakan, Akuntansi, Dan Keuangan Publik, 4(2), 113. https://doi.org/10.25105/jipak.v4i2.4464

Praditasari, N. K. A., \& Setiawan, P. E. (2017). Pengaruh Good Corporate Governance, Ukuran Perusahaan, Leverage Dan Profitabilitas Pada Tax Avoidance. 19(2), 1229-1258.

Rahmawati, L. (2016). Pengaruh Intensitas Modal, Sales Growth, Dan Karakter Eksekutif Terhadap Tax Avoidance Dengan Leverage Sebagai Variabel Intervening. 1-23.

Renata, D. A. (2019). Pengaruh Leverage, Temporary Book-Tax Differences Dan Invesment Opportunity Set Terhadap Kualitas Laba (Studi Pada Perusahaan Manufaktur Yang Terdaftar Di Bursa Efek Indonesia Periode 2015-2018). 1-123.

Ryzki, M. Q. A., \& Fuadi, R. (2019). Pengaruh Corporate Social Responsibility, Sales Growth, Dan Profitabilitas Terhadap Tax Avoidance (Studi Pada Perusahaan Manufaktur Yang Terdaftar Di Bursa Efek Indonesia Tahun 2014-2017). Jurnal Ilmiah Mahasiswa Ekonomi Akuntansi, 4(3), 547-557.

Saputra, M. D., Susanti, J., \& Istiarto. (2019). Pengaruh Profitabilitas, Kepemilikan Keluarga Dan Corporate Governance Terhadap Penghindaran Pajak Di Indonesia. 16(2), 164-179.

Setiyanto, A. I., \& Nurzilla. (2019). Pengaruh piutang dan ukuran perusahaan terhadap sales growth. 7(1), 56-65.

Sholeha, Y. M. A. (2019). Pengaruh Capital Intensity, Profitabilitas, Dan Sales Growth Terhadap Tax Avoidance. Jurnal Akuntansi Bisnis, 1-24.

Silvia, Y. S. (2017). Pengaruh Manajemen Laba, Umur Perusahaan, Ukuran Perusahaan Dan Pertumbuhan Penjualan Terhadap Tax Avoidance. Jurnal Equity, 3(4).

Tandean, V. A. (2015). Pengaruh Good Corporate Governance Dan Ukuran Perusahaan Terhadap Tax Avoidance.

Victory, G., \& Cheisviyani, C. (2016). Pengaruh Tax Avoidance Jangka Panjang Terhadap Nilai Perusahaan Dengan Kepemilikan Institusional Sebagai Variabel Pemoderasi (Studi Empiris Pada Perusahaan Manufaktur Yang Terdaftar Di Bei Periode 2011-2012). $4(1), 755-766$.

Wijayani, D. R. (2014). Pengaruh Profitabilitas, Kepemilikan Keluarga,Corporate Governance Dan Kepemilikan Institusional Terhadap Penghindaraan Pajak Di Indonesia. 13(2), 181-192.

Winata, F. (2014). Pengaruh Corporate Governance Terhadap Tax Avoidance Pada Perusahaan Yang Terdaftar Di Bursa Efek Indonesia Tahun 2013. Tax \& Accounting Review, 4 (1)(1), 1-11.

Yulyanah, Y., \& Kusumastuti, S. Y. (2019). Tax Avoidance Pada Perusahaan Manufaktur Sektor Industri Barang Dan Konsumsi Sub Sektor Makanan Dan Minuman Yang Terdaftar Di Bursa Efek Indonesia Periode 2013-2017. Media Ekonomi, 27(1), 17-36. https://doi.org/10.25105/me.v27i1.5284

Zemzem, A., \& Ftouhi, K. (2013). The Effects of Board of Directors ' Characteristics on Tax Aggressiveness. Research Journal in Finance and Accounting, 4(4), 140-148. 
Zulaecha, H. E., \& Mulvitasari, A. (2014). Pengaruh Likuiditas, Leverage, Dan Sales Growth Terhadapfinancial Distress. 8(1), 16-23.

\section{Lampiran}

\section{Lampiran 1. Data Excel Penelitian}

\begin{tabular}{|c|c|c|c|c|c|c|c|}
\hline $\begin{array}{c}\text { KODE } \\
\text { PERUSAHAAN }\end{array}$ & & $\begin{array}{l}\text { Sales } \\
\text { Growth }\end{array}$ & ETR & Kpmlk in & ROA & $\begin{array}{c}\text { Firm } \\
\text { Size }\end{array}$ & $\begin{array}{l}\text { Moder } \\
\text { asi }\end{array}$ \\
\hline \multirow{3}{*}{ AGII } & 201 & 0.1153875 & & 0.934419 & 0.0179 & 28.880 & 0.1078 \\
\hline & 4 & 9 & 0.2663 & 817 & 42 & 12 & 2 \\
\hline & 201 & 0.2296176 & 0.3172 & 0.934415 & 0.0096 & 29.231 & 0.2145 \\
\hline \multirow[t]{2}{*}{ AGII } & 5 & 29 & 68 & 246 & 92 & 11 & 58 \\
\hline & 201 & 0.1360850 & 0.2687 & 0.655328 & 0.0109 & 29.397 & 0.0891 \\
\hline \multirow[t]{2}{*}{ AGII } & 6 & 95 & 6 & 008 & 94 & 07 & 8 \\
\hline & 201 & 0.1018707 & 0.2706 & 0.655328 & 0.0152 & 29.487 & 0.0667 \\
\hline \multirow[t]{2}{*}{ AGII } & 7 & 94 & 77 & 008 & 41 & 87 & 59 \\
\hline & 201 & 0.1449575 & 0.4345 & 0.900364 & 0.0155 & 21.523 & 0.1305 \\
\hline \multirow[t]{2}{*}{ AKPI } & 4 & 74 & 17 & 706 & 63 & 94 & 15 \\
\hline & 201 & 0.0357299 & 0.4594 & 0.900364 & 0.0095 & 21.782 & 0.0321 \\
\hline \multirow[t]{2}{*}{ AKPI } & 5 & 52 & 15 & 706 & 88 & 15 & 7 \\
\hline & 201 & 0.0145328 & 0.3101 & 0.900364 & 0.0200 & 21.684 & 0.0130 \\
\hline \multirow[t]{2}{*}{ AKPI } & 6 & 86 & 79 & 706 & 29 & 88 & 85 \\
\hline & 201 & 0.0085424 & 0.5808 & 0.766434 & 0.0048 & 21.733 & 0.0065 \\
\hline \multirow[t]{2}{*}{ AKPI } & 7 & 76 & 95 & 381 & 57 & 17 & 47 \\
\hline & 201 & 0.1914141 & 0.2531 & 0.584055 & 0.0590 & 19.692 & 0.1117 \\
\hline \multirow[t]{2}{*}{ ALDO } & 4 & 43 & 83 & 944 & 25 & 73 & 97 \\
\hline & 201 & 0.0826226 & 0.2580 & 0.584055 & 0.0657 & 19.718 & 0.0482 \\
\hline \multirow[t]{2}{*}{ ALDO } & 5 & 91 & 58 & 944 & 88 & 17 & 56 \\
\hline & 201 & 0.1921735 & 0.2546 & 0.849188 & 0.0614 & 19.832 & 0.1631 \\
\hline ALDO & 6 & 69 & 16 & 894 & 87 & 47 & 92 \\
\hline
\end{tabular}




\begin{tabular}{|c|c|c|c|c|c|c|c|}
\hline & 201 & 0.0596931 & 0.2482 & & 0.0582 & 20.027 & 0.0506 \\
\hline \multirow[t]{2}{*}{ ALDO } & 7 & 74 & 01 & 0.84898 & 21 & 52 & 78 \\
\hline & 201 & 0.1196312 & 0.1709 & 0.555335 & 0.0837 & 30.668 & 0.0664 \\
\hline \multirow[t]{2}{*}{ CPIN } & 4 & 21 & 86 & 127 & 22 & 97 & 35 \\
\hline & 201 & 0.0318008 & 0.1968 & 0.555335 & 0.0742 & 30.837 & 0.0176 \\
\hline \multirow[t]{2}{*}{ CPIN } & 5 & 73 & 02 & 127 & 4 & 21 & 6 \\
\hline & 201 & 0.2130109 & 0.4347 & 0.555335 & 0.0930 & 30.817 & 0.1182 \\
\hline \multirow[t]{2}{*}{ CPIN } & 6 & 64 & 38 & 127 & 31 & 58 & 92 \\
\hline & 201 & 0.2250580 & 0.2331 & 0.555335 & 0.1018 & 30.830 & 0.1249 \\
\hline \multirow[t]{2}{*}{ CPIN } & 7 & 78 & 04 & 127 & 16 & 62 & 83 \\
\hline & 201 & 0.0108679 & 0.1549 & 0.511841 & 0.0540 & 19.409 & 0.0055 \\
\hline \multirow[t]{3}{*}{ DPNS } & 4 & 28 & 79 & 291 & 02 & 76 & 63 \\
\hline & & - & & & & & - \\
\hline & 201 & 0.1207090 & 0.1667 & 0.511841 & 0.0359 & 19.430 & 0.0617 \\
\hline \multirow[t]{3}{*}{ DPNS } & 5 & 1 & 51 & 291 & 18 & 4 & 8 \\
\hline & & - & & & & & - \\
\hline & 201 & 0.0218559 & 0.1854 & 0.511841 & 0.0337 & 19.506 & 0.0111 \\
\hline \multirow[t]{3}{*}{ DPNS } & 6 & 44 & 65 & 291 & 99 & 31 & 9 \\
\hline & & - & & & & & - \\
\hline & 201 & 0.0417449 & 0.2120 & 0.511841 & 0.0193 & 19.547 & 0.0213 \\
\hline \multirow[t]{2}{*}{ DPNS } & 7 & 12 & 77 & 291 & 3 & 2 & 7 \\
\hline & 201 & 0.2049189 & 0.3056 & 0.754464 & 0.0995 & 19.835 & 0.1546 \\
\hline \multirow[t]{2}{*}{ EKAD } & 4 & 67 & 52 & 198 & 47 & 87 & 04 \\
\hline & 201 & 0.0093389 & 0.2905 & 0.754464 & 0.1207 & 19.780 & 0.0070 \\
\hline \multirow[t]{2}{*}{ EKAD } & 5 & 37 & 73 & 198 & 11 & 87 & 46 \\
\hline & 201 & 0.0652452 & 0.2343 & 0.768098 & 0.1290 & 20.370 & 0.0501 \\
\hline \multirow[t]{2}{*}{ EKAD } & 6 & 61 & 88 & 003 & 89 & 17 & 15 \\
\hline & 201 & 0.1164604 & 0.2577 & 0.763199 & 0.0956 & 20.496 & 0.0888 \\
\hline \multirow[t]{2}{*}{ EKAD } & 7 & 28 & 13 & 72 & 31 & 07 & 83 \\
\hline & 201 & 0.1280183 & 0.2761 & 0.848188 & 0.1573 & 19.675 & 0.1085 \\
\hline \multirow[t]{3}{*}{ IGAR } & 4 & 45 & 2 & 236 & 07 & 21 & 84 \\
\hline & & - & & & & & \\
\hline & 201 & 0.0893668 & 0.1869 & 0.848188 & 0.1339 & 19.765 & - \\
\hline IGAR & 5 & 1 & 19 & 236 & 18 & 99 & 0.0758 \\
\hline
\end{tabular}




$\begin{array}{lccccccc} & 201 & 0.1456404 & 0.2763 & 0.848188 & 0.1577 & 19.901 & 0.1235 \\ \text { IGAR } & 6 & 24 & 66 & 236 & 05 & 07 & 3 \\ & & & & & & & \\ & & - & & & & & - \\ \text { IGAR } & 201 & 0.0405130 & 0.2442 & 0.848188 & 0.1410 & 20.055 & 0.0343 \\ & 7 & 68 & 23 & 236 & 79 & 83 & 6 \\ & & & & & & & \\ \text { INKP } & 201 & 0.0062618 & 0.0015 & 0.527231 & 0.0193 & 25.118 & - \\ & 4 & 6 & 81 & 31 & 73 & 95 & 0.0033 \\ \text { INKP } & 201 & 0.0703171 & 0.0308 & 0.527231 & 0.0316 & 25.298 & 0.0370 \\ & 5 & 86 & 83 & 31 & 41 & 95 & 73\end{array}$

$\begin{array}{cccccccc} & 201 & 0.0418305 & 0.3950 & 0.527231 & 0.0294 & 25.249 & 0.0220 \\ \text { INKP } & 6 & 46 & 4 & 31 & 82 & 65 & 5 \\ & & & & & & & \\ & 201 & 0.1302471 & 0.0958 & 0.527231 & 0.0541 & 25.362 & 0.0686 \\ \text { INKP } & 7 & 31 & 21 & 31 & 38 & 14 & 7\end{array}$

$\begin{array}{cccccccc} & 201 & 0.0165433 & 0.5060 & 0.642569 & 0.0143 & 15.082 & 0.0106 \\ \text { IPOL } & 4 & 17 & 24 & 986 & 66 & 56 & 3\end{array}$

$\begin{array}{cccccccc} & 201 & 0.1456359 & 0.6029 & 0.642569 & 0.0096 & 15.169 & 0.0935 \\ \text { IPOL } & 5 & 1 & 41 & 986 & 15 & 7 & 8\end{array}$

\begin{tabular}{|c|c|c|c|c|c|c|c|}
\hline & 201 & 0.0250511 & 0.3689 & 0.734160 & 0.0229 & 15.150 & 0.0183 \\
\hline \multirow[t]{2}{*}{ IPOL } & 6 & 25 & 32 & 447 & 76 & 79 & 9 \\
\hline & 201 & 0.0165912 & 0.2857 & 0.785739 & 0.0086 & 15.176 & 0.0130 \\
\hline \multirow[t]{2}{*}{ IPOL } & 7 & 52 & 14 & 684 & 87 & 26 & 36 \\
\hline & 201 & 0.1478593 & 0.2893 & 0.576182 & 0.0248 & 30.388 & 0.0851 \\
\hline \multirow[t]{2}{*}{ JPFA } & 4 & 81 & 37 & 852 & 66 & 43 & 94 \\
\hline & 201 & 0.0144949 & 0.2482 & 0.579499 & 0.0305 & 30.473 & \\
\hline \multirow[t]{2}{*}{ JPFA } & 5 & 29 & 42 & 153 & 65 & 57 & 0.0084 \\
\hline & 201 & 0.0684694 & 0.2150 & 0.630896 & 0.1128 & 30.588 & 0.0431 \\
\hline \multirow[t]{2}{*}{ JPFA } & 6 & 88 & 6 & 075 & 05 & 59 & 97 \\
\hline & 201 & 0.0879234 & 0.3635 & 0.631119 & 0.0556 & 30.622 & 0.0554 \\
\hline \multirow[t]{2}{*}{ JPFA } & 7 & 78 & 45 & 939 & 13 & 75 & 9 \\
\hline & 201 & 0.1475299 & 0.2331 & 0.756761 & 0.0475 & 20.682 & 0.1116 \\
\hline KDSI & 4 & 05 & 14 & 728 & 74 & 79 & 45 \\
\hline
\end{tabular}




\begin{tabular}{|c|c|c|c|c|c|c|c|}
\hline \multirow[b]{2}{*}{ KDSI } & 201 & 0.0511760 & 0.2296 & 0.756761 & 0.0097 & 20.886 & 0.0387 \\
\hline & 5 & 58 & 84 & 728 & 45 & 31 & 28 \\
\hline \multirow{3}{*}{ KDSI } & 201 & 0.1410242 & 0.2601 & 0.756761 & 0.0412 & 20.856 & 0.1067 \\
\hline & 6 & 98 & 49 & 728 & 57 & 29 & 22 \\
\hline & 201 & 0.1114138 & 0.2613 & 0.784422 & 0.0519 & 21.007 & 0.0873 \\
\hline \multirow{2}{*}{ KDSI } & 7 & 87 & 24 & 222 & 2 & 16 & 96 \\
\hline & 201 & 0.0142338 & 0.2099 & 0.940115 & 0.0258 & 20.255 & 0.0133 \\
\hline \multirow[t]{2}{*}{ PICO } & 4 & 25 & 52 & 241 & 94 & 86 & 81 \\
\hline & 201 & 0.0071198 & 0.1418 & 0.940115 & 0.0247 & 20.222 & 0.0066 \\
\hline \multirow[t]{2}{*}{ PICO } & 5 & 65 & 83 & 241 & 2 & 04 & 93 \\
\hline & 201 & 0.0090969 & 0.2043 & 0.940115 & 0.0215 & 20.274 & 0.0085 \\
\hline \multirow[t]{2}{*}{ PICO } & 6 & 51 & 27 & 241 & 37 & 74 & 52 \\
\hline & 201 & 0.0553285 & 0.1259 & 0.940115 & 0.0233 & 20.395 & 0.0520 \\
\hline \multirow[t]{2}{*}{ PICO } & 7 & 19 & 74 & 241 & 59 & 09 & 15 \\
\hline & 201 & 0.0381154 & 0.1700 & 0.762374 & 0.1147 & 21.797 & 0.0290 \\
\hline \multirow[t]{2}{*}{ SMBR } & 4 & 24 & 92 & 985 & 2 & 75 & 58 \\
\hline & 201 & 0.1685771 & 0.2012 & 0.762374 & 0.1083 & 21.907 & 0.1285 \\
\hline \multirow[t]{2}{*}{ SMBR } & 5 & 34 & 43 & 985 & 56 & 65 & 19 \\
\hline & 201 & 0.0404253 & 0.2582 & 0.762374 & 0.0593 & 22.197 & 0.0308 \\
\hline \multirow[t]{2}{*}{ SMBR } & 6 & 2 & 16 & 984 & 04 & 77 & 19 \\
\hline & 201 & 0.0185088 & 0.2981 & 0.762374 & 0.0289 & 22.344 & 0.0141 \\
\hline \multirow[t]{2}{*}{ SMBR } & 7 & 86 & 57 & 984 & 8 & 7 & 11 \\
\hline & 201 & 0.1666916 & 0.2307 & 0.962096 & 0.1434 & 21.447 & 0.1603 \\
\hline \multirow[t]{2}{*}{ тото } & 4 & 63 & 83 & 899 & 56 & 13 & 74 \\
\hline & 201 & 0.0987609 & 0.2524 & 0.923613 & 0.1169 & 21.615 & 0.0912 \\
\hline \multirow[t]{3}{*}{ тото } & 5 & 46 & 73 & 023 & 22 & 08 & 17 \\
\hline & & - & & & & & - \\
\hline & 201 & 0.1013311 & 0.3292 & 0.923613 & 0.0652 & 21.671 & 0.0935 \\
\hline \multirow[t]{2}{*}{ тото } & 6 & 63 & 84 & 023 & 99 & 61 & 9 \\
\hline & 201 & 0.0473529 & 0.2614 & 0.923613 & 0.0986 & 21.762 & 0.0437 \\
\hline \multirow[t]{2}{*}{ тото } & 7 & 17 & 12 & 023 & 86 & 3 & 36 \\
\hline & 201 & 0.1193464 & 0.2489 & 0.548296 & 0.2077 & 20.953 & 0.0654 \\
\hline ARNA & 4 & 36 & 47 & 662 & 96 & 72 & 37 \\
\hline
\end{tabular}




\begin{tabular}{|c|c|c|c|c|c|c|c|}
\hline & 201 & 0.2460148 & 0.2544 & 0.481065 & 0.0497 & 21.081 & 0.1183 \\
\hline \multirow[t]{2}{*}{ ARNA } & 5 & 65 & 55 & 328 & 7 & 48 & 5 \\
\hline & 201 & 0.1455391 & 0.2621 & 0.512904 & 0.0592 & 21.157 & 0.0746 \\
\hline \multirow[t]{2}{*}{ ARNA } & 6 & 55 & 33 & 095 & 11 & 13 & 48 \\
\hline & 201 & 0.1275296 & 0.2648 & 0.512999 & 0.0763 & 21.194 & 0.0654 \\
\hline \multirow[t]{2}{*}{ ARNA } & 7 & 67 & 55 & 444 & 01 & 11 & 23 \\
\hline & 201 & 0.1317589 & 0.2527 & 0.888879 & 0.0614 & 26.947 & 0.1171 \\
\hline \multirow[t]{2}{*}{ ADES } & 4 & 98 & 04 & 399 & 44 & 56 & 18 \\
\hline & 201 & 0.1357885 & 0.2566 & 0.888879 & 0.0502 & 27.205 & \\
\hline \multirow[t]{2}{*}{ ADES } & 5 & 7 & 16 & 399 & 72 & 19 & 0.1207 \\
\hline & 201 & 0.2455188 & 0.0922 & 0.915239 & 0.0729 & 27.366 & 0.2247 \\
\hline \multirow[t]{3}{*}{ ADES } & 6 & 51 & 35 & 264 & 02 & 38 & 08 \\
\hline & & - & & & & & - \\
\hline & 201 & 0.0898390 & 0.2515 & 0.915239 & 0.0455 & 27.456 & 0.0822 \\
\hline \multirow[t]{2}{*}{ ADES } & 7 & 4 & 51 & 264 & 13 & 95 & 2 \\
\hline & 201 & 0.3160533 & 0.2789 & 0.920119 & 0.0319 & 20.973 & 0.2908 \\
\hline \multirow[t]{3}{*}{ CEKA } & 4 & 23 & 84 & 328 & 29 & 36 & 07 \\
\hline & & - & & & & & - \\
\hline & 201 & 0.0620055 & 0.2510 & 0.920119 & 0.0717 & 21.119 & 0.0570 \\
\hline \multirow[t]{2}{*}{ CEKA } & 5 & 92 & 84 & 328 & 1 & 24 & 5 \\
\hline & 201 & 0.1530316 & 0.1264 & 0.920119 & 0.1751 & 21.078 & 0.1408 \\
\hline \multirow[t]{2}{*}{ CEKA } & 6 & 06 & 08 & 328 & 08 & 11 & 07 \\
\hline & 201 & 0.0333970 & 0.2498 & 0.920119 & 0.0771 & 21.054 & 0.0307 \\
\hline \multirow[t]{2}{*}{ CEKA } & 7 & 76 & 32 & 328 & 35 & 46 & 29 \\
\hline & 201 & 0.0019369 & 0.2356 & 0.929991 & 0.0657 & 20.939 & 0.0018 \\
\hline \multirow[t]{2}{*}{ DVLA } & 4 & 06 & 75 & 38 & 39 & 38 & 01 \\
\hline & 201 & 0.1548704 & 0.2530 & 0.929991 & 0.0783 & 21.042 & 0.1440 \\
\hline \multirow[t]{2}{*}{ DVLA } & 5 & 61 & 01 & 38 & 95 & 65 & 28 \\
\hline & 201 & 0.1000849 & 0.2907 & 0.924614 & 0.0993 & 21.149 & 0.0925 \\
\hline \multirow[t]{2}{*}{ DVLA } & 6 & 55 & 14 & 676 & 12 & 43 & 4 \\
\hline & 201 & 0.0788818 & 0.2825 & 0.924614 & 0.0988 & 21.218 & 0.0729 \\
\hline \multirow[t]{2}{*}{ DVLA } & 7 & 82 & 54 & 676 & 79 & 5 & 35 \\
\hline & 201 & & 0.2528 & 0.805329 & 0.1028 & 30.851 & 0.1321 \\
\hline ICBP & 4 & 0.1641365 & 63 & 454 & 46 & 08 & 84 \\
\hline
\end{tabular}




\begin{tabular}{|c|c|c|c|c|c|c|c|}
\hline \multirow{3}{*}{ ICBP } & 201 & 0.0541452 & 0.2709 & 0.805329 & 0.1100 & 30.910 & 0.0436 \\
\hline & 5 & 98 & 69 & 454 & 56 & 45 & 05 \\
\hline & 201 & 0.0790625 & 0.2721 & 0.805329 & 0.1256 & 30.994 & 0.0636 \\
\hline \multirow{2}{*}{ ICBP } & 6 & 41 & 76 & 454 & 42 & 93 & 71 \\
\hline & 201 & 0.0320312 & 0.3194 & 0.805329 & 0.1120 & 31.084 & 0.0257 \\
\hline \multirow[t]{2}{*}{ ICBP } & 7 & 59 & 79 & 454 & 57 & 8 & 96 \\
\hline & 201 & 0.1253378 & 0.2927 & 0.500670 & 0.0520 & 32.086 & 0.0627 \\
\hline \multirow[t]{2}{*}{ INDF } & 4 & 99 & 26 & 833 & 96 & 27 & 53 \\
\hline & 201 & 0.0072975 & 0.3487 & 0.500670 & 0.0351 & 32.150 & 0.0036 \\
\hline \multirow[t]{2}{*}{ INDF } & 5 & 46 & 19 & 833 & 92 & 98 & 54 \\
\hline & 201 & 0.0402750 & 0.3429 & 0.500670 & 0.0586 & 32.046 & 0.0201 \\
\hline \multirow[t]{2}{*}{ INDF } & 6 & 15 & 48 & 833 & 76 & 24 & 65 \\
\hline & 201 & 0.0489594 & 0.3281 & 0.500670 & 0.0582 & 32.112 & 0.0245 \\
\hline \multirow[t]{2}{*}{ INDF } & 7 & 9 & 94 & 833 & 01 & 9 & 13 \\
\hline & 201 & 0.3210386 & 0.2492 & & 0.0554 & 21.345 & 0.2809 \\
\hline \multirow[t]{2}{*}{ KINO } & 4 & 58 & 07 & 0.875 & 13 & 66 & 09 \\
\hline & 201 & 0.0733832 & 0.2194 & 0.798855 & 0.0819 & 21.889 & 0.0586 \\
\hline \multirow[t]{3}{*}{ KINO } & 5 & 28 & 32 & 29 & 1 & 92 & 23 \\
\hline & & - & & & & & \\
\hline & 201 & 0.0317257 & 0.1741 & 0.904665 & 0.0551 & 21.912 & - \\
\hline \multirow[t]{3}{*}{ KINO } & 6 & 6 & 94 & 185 & 41 & 48 & 0.0287 \\
\hline & & - & & & & & \\
\hline & 201 & 0.1051661 & 0.2218 & 0.908089 & 0.0338 & 21.898 & - \\
\hline \multirow[t]{2}{*}{ KINO } & 7 & 42 & 21 & 165 & 82 & 1 & 0.0955 \\
\hline & 201 & 0.1518270 & 0.2260 & 0.330651 & 0.0397 & 23.055 & 0.0502 \\
\hline \multirow[t]{2}{*}{ MYOR } & 4 & 62 & 65 & 324 & 77 & 22 & 02 \\
\hline & 201 & 0.0438393 & 0.2378 & 0.330651 & 0.1102 & 23.151 & 0.0144 \\
\hline \multirow[t]{2}{*}{ MYOR } & 5 & 14 & 93 & 324 & 23 & 84 & 96 \\
\hline & 201 & 0.1924379 & 0.2476 & 0.590708 & 0.1074 & 23.282 & 0.1136 \\
\hline \multirow[t]{2}{*}{ MYOR } & 6 & 67 & 09 & 385 & 63 & 23 & 75 \\
\hline & 201 & 0.1184970 & 0.2542 & 0.590708 & 0.1093 & 23.425 & 0.0699 \\
\hline \multirow[t]{2}{*}{ MYOR } & 7 & 28 & 11 & 385 & 44 & 69 & 97 \\
\hline & 201 & 0.1338089 & 0.3680 & 0.538461 & 0.0154 & 18.966 & 0.0720 \\
\hline PYFA & 4 & 63 & 84 & 49 & 21 & 24 & 51 \\
\hline
\end{tabular}




\begin{tabular}{|c|c|c|c|c|c|c|c|}
\hline & 201 & 0.0204641 & 0.3222 & 0.538461 & & 18.890 & 0.0110 \\
\hline \multirow[t]{3}{*}{ PYFA } & 5 & 85 & 83 & 49 & 0.0193 & 38 & 2 \\
\hline & & - & & & & & - \\
\hline & 201 & 0.0041115 & 0.2703 & 0.538461 & 0.0308 & 18.933 & 0.0022 \\
\hline \multirow[t]{2}{*}{ PYFA } & 6 & 09 & 81 & 49 & 03 & 88 & 1 \\
\hline & 201 & 0.0271298 & 0.2575 & 0.538461 & 0.0446 & 18.887 & 0.0146 \\
\hline \multirow[t]{2}{*}{ PYFA } & 7 & 02 & 27 & 49 & 65 & 96 & 08 \\
\hline & 201 & 0.1245036 & 0.1876 & 0.814241 & 0.1379 & 20.297 & 0.1013 \\
\hline \multirow[t]{3}{*}{ SKBM } & 4 & 79 & 31 & 168 & 74 & 05 & 76 \\
\hline & & - & & & & & - \\
\hline & 201 & 0.0846568 & 0.2513 & 0.804862 & 0.0525 & 20.454 & 0.0681 \\
\hline \multirow[t]{2}{*}{ SKBM } & 5 & 36 & 33 & 62 & 2 & 71 & 4 \\
\hline & 201 & 0.0953966 & 0.2682 & 0.806224 & 0.0225 & 20.724 & 0.0769 \\
\hline \multirow[t]{2}{*}{ SKBM } & 6 & 19 & 25 & 985 & 08 & 92 & 11 \\
\hline & 201 & 0.1876545 & 0.1851 & 0.827938 & 0.0159 & 21.207 & 0.1553 \\
\hline \multirow[t]{2}{*}{ SKBM } & 7 & 95 & 64 & 965 & 46 & 56 & 67 \\
\hline & 201 & 0.1678421 & 0.2989 & 0.960911 & 0.0500 & 19.635 & 0.1612 \\
\hline \multirow[t]{2}{*}{ SKLT } & 4 & 53 & 52 & 515 & 28 & 39 & 81 \\
\hline & 201 & 0.0854748 & 0.2669 & 0.960911 & 0.0532 & 19.748 & 0.0821 \\
\hline \multirow[t]{2}{*}{ SKLT } & 5 & 57 & 86 & 515 & 12 & 05 & 34 \\
\hline & 201 & 0.1064244 & 0.1796 & 0.928335 & 0.0363 & 20.158 & 0.0987 \\
\hline \multirow[t]{2}{*}{ SKLT } & 6 & 17 & 07 & 444 & 33 & 05 & 98 \\
\hline & 201 & 0.0878800 & 0.1607 & 0.773107 & 0.0361 & 20.271 & 0.0679 \\
\hline \multirow[t]{2}{*}{ SKLT } & 7 & 77 & 54 & 508 & 02 & 16 & 41 \\
\hline & 201 & 0.2190909 & 0.2639 & 0.598630 & 0.0727 & 21.254 & 0.1311 \\
\hline \multirow[t]{2}{*}{ STTP } & 4 & 41 & 75 & 153 & 18 & 01 & 54 \\
\hline & 201 & 0.1469234 & 0.1995 & 0.598630 & 0.0967 & 21.375 & 0.0879 \\
\hline \multirow[t]{2}{*}{ STTP } & 5 & 1 & 65 & 153 & 43 & 37 & 53 \\
\hline & 201 & 0.0322653 & 0.2000 & 0.567633 & 0.0745 & 21.572 & 0.0183 \\
\hline \multirow[t]{2}{*}{ STTP } & 6 & 28 & 96 & 969 & 24 & 22 & 15 \\
\hline & 201 & 0.0694773 & 0.2513 & 0.567633 & 0.0922 & 21.574 & 0.0394 \\
\hline \multirow[t]{2}{*}{ STTP } & 7 & 75 & 36 & 969 & 22 & 46 & 38 \\
\hline & 201 & 0.0874888 & 0.2133 & 0.775248 & 0.1041 & 22.447 & 0.0678 \\
\hline TSPC & 4 & 1 & 2 & 204 & 6 & 74 & 26 \\
\hline
\end{tabular}




\begin{tabular}{|c|c|c|c|c|c|c|c|}
\hline & 201 & 0.0818148 & 0.2515 & 0.781630 & 0.0842 & 22.561 & 0.0639 \\
\hline \multirow[t]{2}{*}{ TSPC } & 5 & 84 & 76 & 049 & 07 & 39 & 49 \\
\hline & 201 & 0.1046981 & 0.2412 & 0.784186 & 0.0828 & 22.608 & 0.0821 \\
\hline \multirow{2}{*}{ TSPC } & 6 & 81 & 73 & 538 & 29 & 18 & 03 \\
\hline & 201 & 0.0446630 & 0.2509 & 0.789246 & 0.0749 & 22.729 & 0.0352 \\
\hline \multirow[t]{2}{*}{ TSPC } & 7 & 81 & 79 & 049 & 63 & 45 & 5 \\
\hline & 201 & 0.2049347 & 0.2539 & & 0.0880 & 21.485 & 0.1449 \\
\hline \multirow[t]{2}{*}{ ROTI } & 4 & 03 & 34 & 0.7075 & 34 & 42 & 91 \\
\hline & 201 & 0.1265653 & 0.2847 & 0.707597 & 0.0999 & 21.718 & 0.0895 \\
\hline \multirow[t]{2}{*}{ ROTI } & 5 & 32 & 65 & 854 & 65 & 86 & 57 \\
\hline & 201 & 0.1573519 & 0.2426 & 0.707597 & 0.0958 & 21.794 & 0.1113 \\
\hline \multirow[t]{2}{*}{ ROTI } & 6 & 72 & 5 & 854 & 26 & 73 & 42 \\
\hline & 201 & 0.0405913 & 0.2728 & 0.702826 & 0.0296 & 22.240 & 0.0285 \\
\hline \multirow[t]{2}{*}{ ROTI } & 7 & 7 & 11 & 48 & 88 & 5 & 29 \\
\hline & 201 & 0.1053495 & 0.2842 & 0.871503 & 0.0919 & 20.468 & 0.0918 \\
\hline \multirow[t]{2}{*}{ BATA } & 4 & 09 & 81 & 769 & 43 & 23 & 12 \\
\hline & 201 & 0.0195587 & 0.0907 & 0.871087 & 0.1628 & 20.494 & 0.0170 \\
\hline \multirow[t]{3}{*}{ BATA } & 5 & 12 & 37 & 308 & 64 & 18 & 37 \\
\hline & & - & & & & & - \\
\hline & 201 & 0.0290547 & 0.3532 & 0.871087 & 0.0524 & 20.506 & 0.0253 \\
\hline \multirow[t]{3}{*}{ BATA } & 6 & 53 & 82 & 308 & 79 & 03 & 1 \\
\hline & & - & & & & & - \\
\hline & 201 & 0.0259261 & 0.3253 & & 0.0627 & 20.567 & 0.0225 \\
\hline \multirow[t]{3}{*}{ BATA } & 7 & 84 & 11 & 0.871045 & 03 & 42 & 8 \\
\hline & & - & & & & & - \\
\hline & 201 & 0.2929799 & 0.3333 & 0.930582 & 0.0152 & 20.614 & 0.2726 \\
\hline \multirow[t]{2}{*}{ IKBI } & 4 & 43 & 33 & 68 & 63 & 07 & 4 \\
\hline & 201 & 0.0718085 & & 0.930582 & 0.0238 & 20.764 & 0.0668 \\
\hline \multirow[t]{3}{*}{ IKBI } & 5 & 11 & 0.28 & 68 & 38 & 08 & 24 \\
\hline & & - & & & & & - \\
\hline & 201 & 0.1489686 & 0.2758 & 0.930582 & 0.0286 & 20.754 & 0.1386 \\
\hline \multirow[t]{3}{*}{ IKBI } & 6 & 78 & 62 & 68 & 57 & 26 & 3 \\
\hline & & - & & & & & - \\
\hline & 201 & 0.0147286 & 0.2575 & 0.921965 & 0.0598 & 20.826 & 0.0135 \\
\hline IKBI & 7 & 82 & 76 & 686 & 95 & 15 & 8 \\
\hline
\end{tabular}




\begin{tabular}{|c|c|c|c|c|c|c|c|}
\hline & 201 & 0.1231585 & 0.2510 & 0.794439 & 0.0316 & 20.288 & 0.0978 \\
\hline \multirow[t]{2}{*}{ KBLM } & 4 & 86 & 69 & 196 & 49 & 93 & 4 \\
\hline & 201 & 0.0497793 & 0.4057 & 0.825423 & 0.0194 & 20.299 & 0.0410 \\
\hline \multirow[t]{2}{*}{ KBLM } & 5 & 76 & 19 & 929 & 99 & 21 & 89 \\
\hline & 201 & 0.0199501 & 0.4254 & 0.824127 & 0.0310 & 20.275 & 0.0164 \\
\hline \multirow[t]{2}{*}{ KBLM } & 6 & 93 & 11 & 411 & 44 & 56 & 42 \\
\hline & 201 & 0.1876366 & 0.0124 & 0.815518 & 0.0356 & 20.934 & 0.1530 \\
\hline \multirow[t]{2}{*}{ KBLM } & 7 & 23 & 14 & 929 & 18 & 5 & 21 \\
\hline & 201 & 0.1031669 & 0.2560 & 0.629083 & 0.0415 & 20.911 & 0.0649 \\
\hline \multirow[t]{3}{*}{ NIPS } & 4 & 47 & 47 & 397 & 42 & 28 & 01 \\
\hline & & - & & & & & - \\
\hline & 201 & 0.0283490 & & 0.629083 & 0.0198 & 21.160 & 0.0178 \\
\hline \multirow[t]{2}{*}{ NIPS } & 5 & 73 & 0.2654 & 397 & 17 & 05 & 3 \\
\hline & 201 & 0.0497991 & 0.2583 & 0.595925 & 0.0369 & 21.298 & 0.0296 \\
\hline \multirow[t]{2}{*}{ NIPS } & 6 & 6 & 72 & 431 & 43 & 73 & 77 \\
\hline & 201 & 0.0347347 & 0.2608 & 0.503653 & 0.0232 & 21.364 & 0.0174 \\
\hline \multirow[t]{3}{*}{ NIPS } & 7 & 89 & 5 & 308 & 41 & 05 & 94 \\
\hline & & - & & & & & - \\
\hline & 201 & 0.1393612 & 0.2790 & 0.461924 & 0.0253 & 22.242 & 0.0643 \\
\hline \multirow[t]{3}{*}{ PBRX } & 4 & 61 & 7 & 667 & 2 & 61 & 7 \\
\hline & & - & & & & & \\
\hline & 201 & 0.1519350 & 0.2521 & 0.515983 & 0.0194 & 22.532 & - \\
\hline \multirow[t]{3}{*}{ PBRX } & 5 & 22 & 74 & 584 & 22 & 93 & 0.0784 \\
\hline & & - & & & & & - \\
\hline & 201 & 0.2366322 & 0.2732 & 0.531540 & 0.0256 & 22.666 & 0.1257 \\
\hline \multirow[t]{2}{*}{ PBRX } & 6 & 01 & 24 & 891 & 02 & 32 & 8 \\
\hline & 201 & 0.0035325 & 0.2818 & 0.478520 & 0.0136 & 22.773 & 0.0016 \\
\hline \multirow[t]{3}{*}{ PBRX } & 7 & 29 & 18 & 924 & 03 & 33 & 9 \\
\hline & & - & & & & & - \\
\hline & 201 & 0.0129004 & 0.2452 & 0.672601 & 0.0831 & 21.227 & 0.0086 \\
\hline \multirow[t]{3}{*}{ SCCO } & 4 & 98 & 91 & 193 & 03 & 68 & 8 \\
\hline & & - & & & & & - \\
\hline & 201 & 0.0481695 & 0.2277 & 0.711514 & 0.0897 & 21.296 & 0.0342 \\
\hline SCCO & 5 & 72 & 88 & 84 & 39 & 02 & 7 \\
\hline
\end{tabular}




\begin{tabular}{|c|c|c|c|c|c|c|c|}
\hline \multirow[b]{2}{*}{ SCCO } & 201 & 0.0559917 & 0.2252 & 0.711514 & 0.1390 & 21.619 & 0.0398 \\
\hline & 6 & 9 & 22 & 84 & 22 & 33 & 39 \\
\hline \multirow{3}{*}{ SCCO } & 201 & 0.1571403 & 0.2186 & 0.711514 & 0.0671 & 22.113 & 0.1118 \\
\hline & 7 & 96 & 95 & 84 & 93 & 12 & 08 \\
\hline & 201 & 0.0714649 & 0.2352 & & 0.0722 & 22.885 & 0.0400 \\
\hline \multirow[t]{2}{*}{ SRIL } & 4 & 47 & 05 & 0.560713 & 56 & 94 & 71 \\
\hline & 201 & 0.0668461 & 0.1377 & 0.642733 & 0.0711 & 23.103 & 0.0429 \\
\hline \multirow[t]{2}{*}{ SRIL } & 5 & 9 & 71 & 135 & 09 & 33 & 64 \\
\hline & 201 & & 0.1015 & & 0.0627 & 23.266 & 0.0400 \\
\hline \multirow[t]{2}{*}{ SRIL } & 6 & 0.0714811 & 15 & 0.560713 & 11 & 96 & 8 \\
\hline & 201 & 0.1045699 & 0.0568 & 0.600648 & 0.0570 & 23.505 & 0.0628 \\
\hline SRIL & 7 & 99 & 65 & 181 & 04 & 89 & 1 \\
\hline
\end{tabular}

\section{Lampiran 2. Tabel Statistik Deskriptif}

\begin{tabular}{|c|c|c|c|c|c|c|}
\hline & ___ETR & $\begin{array}{l}\text { _1_FIRM_S } \\
\text { IZE }\end{array}$ & $\begin{array}{c}\text { _1_KPMLK } \\
\text { _IN }\end{array}$ & $\begin{array}{c}\text {-1_MODER } \\
\text { ASI }\end{array}$ & _1_ROA & $\begin{array}{c}\text { _1_SALES_GRO } \\
\text { WTH }\end{array}$ \\
\hline \multirow{3}{*}{ Mean } & 9.4913 & & & & 27.942 & \\
\hline & 48 & 0.045385 & 1.451024 & 18.77173 & 52 & 14.07328 \\
\hline & 3.9358 & & & & 17.762 & \\
\hline Median & 83 & 0.0469 & 1.31169 & 11.40598 & 04 & 8.005162 \\
\hline \multirow[t]{3}{*}{ Maximum } & 632.5 & 0.066302 & 3.024334 & 591.5798 & $\begin{array}{c}205.88 \\
92\end{array}$ & 516.2872 \\
\hline & - & & & & & \\
\hline & 2.5313 & & & & 4.8124 & \\
\hline \multirow[t]{2}{*}{ Minimum } & 6 & 0.031103 & 1.039396 & -451.694 & 22 & -243.22 \\
\hline & 53.509 & & & & 27.423 & \\
\hline \multirow[t]{2}{*}{ Std. Dev. } & 96 & 0.006879 & 0.374643 & 94.68304 & 25 & 63.59355 \\
\hline & 11.411 & & & & 2.9657 & \\
\hline \multirow[t]{2}{*}{ Skewness } & 46 & -0.12559 & 1.286485 & 1.917952 & 84 & 3.608995 \\
\hline & 133.17 & & & & 15.794 & \\
\hline Kurtosis & 15 & 4.341965 & 5.491598 & 23.18151 & 9 & 33.31527 \\
\hline
\end{tabular}




\begin{tabular}{|c|c|c|c|c|c|c|}
\hline Jarque- & 10188 & & & & 1160.2 & \\
\hline Bera & 2.1 & 10.87311 & 74.83136 & 2461.712 & 08 & 5664.838 \\
\hline Probabilit & & & & & & \\
\hline $\mathrm{y}$ & 0 & 0.004354 & 0 & 0 & 0 & 0 \\
\hline & 1328.7 & & & & 3911.9 & \\
\hline Sum & 89 & 6.353937 & 203.1434 & 2628.042 & 53 & 1970.259 \\
\hline Sum Sq. & 39800 & & & & 10453 & \\
\hline Dev. & 0.8 & 0.006577 & 19.50965 & 1246118 & 2.8 & 562135.4 \\
\hline Observatio & & & & & & \\
\hline ns & 140 & 140 & 140 & 140 & 140 & 140 \\
\hline
\end{tabular}




\section{Lampiran 3. Tabel Hasil Uji Unit Root Sales Growth (Level)}

Panel unit root test: Summary

Series:_1_SALES_GROWTH

Date: 04/06/20 Time: 20:08

Sample: 20142017

Exogenous variables: Individual effects

Automatic selection of maximum lags

Automatic lag length selection based on SIC: 0

Newey-West automatic bandwidth selection and Bartlett kernel

Balanced observations for each test

Cross-

Method Statistic Prob.** sections Obs

Null: Unit root (assumes common unit root process)

Levin, Lin \& Chu t* $\quad-132.255 \quad 0 \quad 35 \quad 105$

Null: Unit root (assumes individual unit root process)

$\begin{array}{lrrrr}\text { ADF - Fisher Chi-square } & 106.884 & 0.003 & 35 & 105 \\ \text { PP - Fisher Chi-square } & 123.58 & 0.0001 & 35 & 105\end{array}$

** Probabilities for Fisher tests are computed using an asymptotic Chi -square distribution. All other tests assume asymptotic normality. 


\section{Lampiran 4. Tabel Hasil Uji Unit Root ETR (Level)}

Panel unit root test: Summary

Series:_1_ETR

Date: 04/06/20 Time: 20:00

Sample: 20142017

Exogenous variables: Individual effects

Automatic selection of maximum lags

Automatic lag length selection based on SIC: 0

Newey-West automatic bandwidth selection and Bartlett kernel

Balanced observations for each test

Cross-

Method

Statistic Prob.** sections Obs

Null: Unit root (assumes common unit root process)

Levin, Lin \& Chu t* $\quad-18.4247 \quad 0 \quad 35 \quad 105$

Null: Unit root (assumes individual unit root process)

$\begin{array}{lcccc}\text { ADF - Fisher Chi-square } & 107.025 & 0.0029 & 35 & 105 \\ \text { PP - Fisher Chi-square } & 128.147 & 0 & 35 & 105\end{array}$

** Probabilities for Fisher tests are computed using an asymptotic Chi -square distribution. All other tests assume asymptotic normality.

\section{Lampiran 5. Tabel Hasil Uji Unit Root Firm Size (Level)}

Panel unit root test: Summary

Series: _1_FIRM_SIZE

Date: 04/06/20 Time: 21:45

Sample: 20142017 
Exogenous variables: Individual effects

Automatic selection of maximum lags

Automatic lag length selection based on SIC: 0

Newey-West automatic bandwidth selection and Bartlett kernel

Balanced observations for each test

Cross-

Method Statistic Prob.** sections Obs

Null: Unit root (assumes common unit root process)

Levin, Lin \& Chu t* $\quad-1.85739 \quad 0.0316$

$35 \quad 105$

Null: Unit root (assumes individual unit root process)

ADF - Fisher Chi-square $170.568 \quad 0$

PP - Fisher Chi-square $196.916 \quad 0$

$35 \quad 105$

$35 \quad 105$

** Probabilities for Fisher tests are computed using an asymptotic Chi

-square distribution. All other tests assume asymptotic normality.

Lampiran 6. Tabel Hasil Uji Unit Root Kepemilikan Institusional (Level) Panel unit root test: Summary

Series: D(_1_KPMLK_IN)

Date: 04/06/20 Time: $23: 33$

Sample: 20142017

Exogenous variables: None

Automatic selection of maximum lags

Automatic lag length selection based on SIC: 0

Newey-West automatic bandwidth selection and Bartlett kernel

Balanced observations for each test 
Cross-

Method Statistic Prob.** sections Obs

Null: Unit root (assumes common unit root process)

Levin, Lin \& Chu t* $\quad-8.67321 \quad 0 \quad 17 \quad 34$

Null: Unit root (assumes individual unit root process)

$\begin{array}{ccccc}\text { ADF - Fisher Chi-square } & 78.3362 & 0 & 17 & 34 \\ \text { PP - Fisher Chi-square } & 78.3025 & 0 & 17 & 34\end{array}$

** Probabilities for Fisher tests are computed using an asymptotic Chi

-square distribution. All other tests assume asymptotic normality.

\section{Lampiran 7. Tabel Hasil Uji Unit Root ROA (Level)}

Panel unit root test: Summary

Series:_1_ROA

Date: 04/06/20 Time: 20:09

Sample: 20142017

Exogenous variables: Individual effects

Automatic selection of maximum lags

Automatic lag length selection based on SIC: 0

Newey-West automatic bandwidth selection and Bartlett kernel

Balanced observations for each test

Cross-

Method Statistic Prob.** sections Obs

Null: Unit root (assumes common unit root process)

Levin, Lin \& Chu $t^{*} \quad-68.9898 \quad 0 \quad 35 \quad 105$ 
Null: Unit root (assumes individual unit root process)

$\begin{array}{lcccc}\text { ADF - Fisher Chi-square } & 120.98 & 0.0002 & 35 & 105 \\ \text { PP - Fisher Chi-square } & 132.934 & 0 & 35 & 105\end{array}$

** Probabilities for Fisher tests are computed using an asymptotic Chi -square distribution. All other tests assume asymptotic normality.

\section{Lampiran 8. Tabel Hasil Uji Statistik F (Uji Chow)}

Redundant Fixed Effects Tests

Equation: Untitled

Test cross-section fixed effects

$\begin{array}{cccc}\text { Effects Test } & \text { Statistic } & \text { d.f. } & \text { Prob. } \\ \text { Cross-section F } & 3.621378 & -34,101 & 0 \\ \text { Cross-section Chi-square } & 111.5928 & 34 & 0\end{array}$

Cross-section fixed effects test equation:

Dependent Variable:_1_ETR

Method: Panel Least Squares

Date: 04/06/20 Time: 21:01

Sample: 20142017

Periods included: 4

Cross-sections included: 35

Total panel (balanced) observations: 140

Variable

Coefficient Std. Error t-Statistic Prob. 


\begin{tabular}{|c|c|c|c|c|}
\hline _1_SALES_GROWTH & 0.564135 & 0.239777 & 2.352746 & 0.0201 \\
\hline _1_KPMLK_IN & 18.32464 & 11.95856 & 1.532345 & 0.1278 \\
\hline _1_MODERASI & -0.53859 & 0.161102 & -3.34316 & 0.0011 \\
\hline _1_FIRM_SIZE & -973.507 & 649.6956 & -1.49841 & 0.1364 \\
\hline _1_ROA & 0.212392 & 0.159228 & 1.333886 & 0.1845 \\
\hline $\mathrm{C}$ & 23.32098 & 36.49682 & 0.638987 & 0.5239 \\
\hline R-squared & 0.147009 & \multicolumn{2}{|c|}{ Mean dependent var } & 9.491348 \\
\hline Adjusted R-squared & 0.115181 & \multicolumn{2}{|c|}{ S.D. dependent var } & 53.50996 \\
\hline S.E. of regression & 50.33405 & \multicolumn{2}{|c|}{ Akaike info criterion } & 10.71715 \\
\hline Sum squared resid & 339491.2 & \multicolumn{2}{|c|}{ Schwarz criterion } & 10.84322 \\
\hline Log likelihood & -744.201 & \multicolumn{2}{|c|}{ Hannan-Quinn criter. } & 10.76838 \\
\hline F-statistic & 4.618851 & \multicolumn{2}{|c|}{ Durbin-Watson stat } & 1.918479 \\
\hline Prob(F-statistic) & 0.00064 & & & \\
\hline
\end{tabular}

\section{Lampiran 9. Tabel Hasil Uji Hausman}

Correlated Random Effects - Hausman Test

Equation: Untitled

Test cross-section random effects

Test Summary

Cross-section random
Chi-Sq. Statistic Chi-Sq. d.f. Prob.

$$
2.255254
$$

5

0.8128

** WARNING: estimated cross-section random effects variance is zero.

Cross-section random effects test comparisons: 


$\begin{array}{ccccc}\text { Variable } & \text { Fixed } & \text { Random } & \text { Var(Diff.) } & \text { Prob. } \\ & & & & \\ \text { _1_SALES_GROWTH } & 0.442638 & 0.564135 & 0.022797 & 0.421 \\ \text { _1_KPMLK_IN } & 5.28287 & 18.32464 & 859.4179 & 0.6564 \\ \text { _1_MODERASI } & -0.44601 & -0.53859 & 0.009261 & 0.336 \\ \text { _1_FIRM_SIZE } & 1060.748 & -973.507 & 1.39 \mathrm{E}+08 & 0.8631 \\ \text { _1_ROA } & 0.430402 & 0.212392 & 0.056931 & 0.3609\end{array}$

Cross-section random effects test equation:

Dependent Variable:_1_ETR

Method: Panel Least Squares

Date: 04/06/20 Time: 20:58

Sample: 20142017

Periods included: 4

Cross-sections included: 35

Total panel (balanced) observations: 140

$\begin{array}{ccccc}\text { Variable } & \text { Coefficient } & \text { Std. Error } & \text { t-Statistic } & \text { Prob. } \\ & & & & \\ \text { C } & -56.2001 & 534.4278 & -0.10516 & 0.9165 \\ \text { _1_SALES_GROWTH } & 0.442638 & 0.28556 & 1.550069 & 0.1243 \\ \text { _1_KPMLK_IN } & 5.28287 & 31.71034 & 0.166598 & 0.868 \\ \text { _1_MODERASI } & -0.44601 & 0.189159 & -2.35785 & 0.0203 \\ \text { _1_FIRM_SIZE } & 1060.748 & 11813.21 & 0.089793 & 0.9286 \\ \text { _1_ROA } & 0.430402 & 0.287816 & 1.49541 & 0.138\end{array}$

Effects Specification 
Cross-section fixed (dummy variables)

\begin{tabular}{cccc} 
R-squared & 0.349548 & Mean dependent var & 9.491348 \\
Adjusted R-squared & 0.095872 & S.D. dependent var & 53.50996 \\
S.E. of regression & 50.88029 & Akaike info criterion & 10.93178 \\
Sum squared resid & 258880.4 & Schwarz criterion & 11.77225 \\
Log likelihood & -725.225 & Hannan-Quinn criter. & 11.27333 \\
F-statistic & 1.37793 & Durbin-Watson stat & 2.094261 \\
Prob(F-statistic) & 0.103554 & & \\
\hline
\end{tabular}

\section{Lampiran 10. Tabel Hasil Estimasi Model Random Effect ETR}

Dependent Variable:_1_ETR

Method: Panel EGLS (Cross-section random effects)

Date: 04/06/20 Time: 20:59

Sample: 20142017

Periods included: 4

Cross-sections included: 35

Total panel (balanced) observations: 140

Swamy and Arora estimator of component variances

$\begin{array}{ccccc}\text { Variable } & \text { Coefficient } & \text { Std. Error } & \text { t-Statistic } & \text { Prob. } \\ \text { _1_SALES_GROWTH } & 0.564135 & 0.242379 & 2.327487 & 0.0214 \\ \text { _1_KPMLK_IN } & 18.32464 & 12.08834 & 1.515893 & 0.1319 \\ \text { _1_MODERASI } & -0.53859 & 0.16285 & -3.30727 & 0.0012 \\ \text { _1_FIRM_SIZE } & -973.507 & 656.7463 & -1.48232 & 0.1406 \\ \text { _1_ROA } & 0.212392 & 0.160956 & 1.319566 & 0.1892\end{array}$


Effects Specification

S.D.

Rho

Cross-section random

0

0

Idiosyncratic random

50.88029

1

Weighted Statistics

$\begin{array}{cccc}\text { R-squared } & 0.147009 & \text { Mean dependent var } & 9.491348 \\ \text { Adjusted R-squared } & 0.115181 & \text { S.D. dependent var } & 53.50996 \\ \text { S.E. of regression } & 50.33405 & \text { Sum squared resid } & 339491.2 \\ \text { F-statistic } & 4.618851 & \text { Durbin-Watson stat } & 1.918479 \\ \text { Prob(F-statistic) } & 0.00064 & & \end{array}$

Unweighted Statistics

R-squared

0.147009

Mean dependent var

9.491348

Sum squared resid

339491.2

Durbin-Watson stat

1.918479

\section{Lampiran 11. Tabel Hasil Uji lagrange multiplier (LM)}

Lagrange multiplier (LM) test for panel data

Date: 04/06/20 Time: 21:04

Sample: 20142017

Total panel observations: 140

Probability in 0

Null (no rand. effect)

Cross-section

Period

Both 


\begin{tabular}{cccc} 
Alternative & One-sided & \multicolumn{2}{c}{ One-sided } \\
Breusch-Pagan & 47.8901 & 1.124687 & 49.01479 \\
& 0 & -0.2889 & 0 \\
Honda & 6.920268 & -1.06051 & 4.143472 \\
& 0 & -0.8555 & 0 \\
King-Wu & 6.920268 & -1.06051 & 0.953918 \\
& 0 & -0.8555 & -0.1701 \\
GHM & -- & -- & 47.8901 \\
& -- & -- & 0
\end{tabular}

\section{Lampiran 12. Tabel Hasil Uji Random Effect Sebelum Moderasi}

Dependent Variable:_1_ETR

Method: Panel EGLS (Cross-section random effects)

Date: 05/14/20 Time: 19:26

Sample: 20142017

Periods included: 4

Cross-sections included: 35

Total panel (balanced) observations: 140

Swamy and Arora estimator of component variances

$\begin{array}{ccccc}\text { Variable } & \text { Coefficient } & \text { Std. Error } & \text { t-Statistic } & \text { Prob. } \\ & & & & \\ \text { _1_SALES_GROWTH } & -0.204 & 0.071371 & -2.85829 & 0.0049 \\ \text { _1_KPMLK_IN } & 9.121795 & 12.65414 & 0.720855 & 0.4722 \\ \text { _1_FIRM_SIZE } & -738.403 & 706.8245 & -1.04468 & 0.298 \\ \text { _1_ROA } & 0.212213 & 0.171026 & 1.240827 & 0.2168\end{array}$


Effects Specification

S.D.

Rho

Cross-section random

9.223523

0.0305

Idiosyncratic random

52.01606

0.9695

Weighted Statistics

$\begin{array}{cccc}\text { R-squared } & 0.074417 & \text { Mean dependent var } & 8.945466 \\ \text { Adjusted R-squared } & 0.046992 & \text { S.D. dependent var } & 52.71409 \\ \text { S.E. of regression } & 51.46061 & \text { Sum squared resid } & 357506.2 \\ \text { F-statistic } & 2.713507 & \text { Durbin-Watson stat } & 1.94265 \\ \text { Prob(F-statistic) } & 0.032573 & & \end{array}$

Unweighted Statistics

R-squared

0.075845

Mean dependent var

9.491348

Sum squared resid

367814.4

Durbin-Watson stat

1.915347 